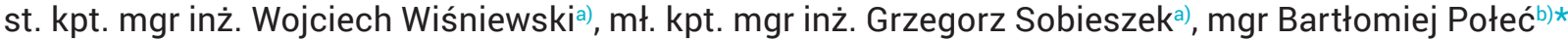

\author{
${ }^{a}$ Komenda Wojewódzka Państwowej Straży Pożarnej w Warszawie / Mazovian Headquarters of the State Fire Service \\ ${ }^{b}$ Centrum Naukowo-Badawcze Ochrony Przeciwpożarowej- Państwowy Instytut Badawczy / Scientific and Research Centre for Fire \\ Protection National Research Institute \\ *Autor korespondencyjny / Corresponding author: bpolec@cnbop.pl
}

\section{Zapobieganie poważnym awariom przemysłowym - studium przypadku na przykładzie województwa mazowieckiego}

\author{
Prevention of Major industrial accidents - Case Study Using the Example \\ of the Mazowieckie Voivodeship
}

\author{
Предотвращение серьезных несчастных случаев на производстве - комплексный \\ анализ на примере Мазовецкого воеводства
}

\begin{abstract}
ABSTRAKT
Cel: Niniejszy artykuł ma na celu ocenę stanu realizacji w Polsce obowiązującej doktryny zapobiegania poważnym awariom przemysłowym w kontekście zapewnienia bezpiecznej odległości w procesie kształtowania ładu przestrzennego.

Wprowadzenie: Właściciele zakładów o dużym ryzyku wystąpienia poważnej awarii przemysłowej są zobowiązani do przeprowadzania analizy takiego ryzyka oraz jego oceny. W raportach o bezpieczeństwie dla tego rodzaju zakładów zawarte są szczegółowe założenia i opis procesu analizy i oceny ryzyka oraz jego wyniki przedstawione także w formie graficznej. Jednym z najważniejszych elementów tego procesu są wytypowane reprezentatywne zdarzenia awaryjne, rozwinięte w reprezentatywne scenariusze awaryjne. Od stopnia ich dokładności i adekwatności dla danego rodzaju instalacji i parametrów procesu przemysłowego zależy końcowa wartość analizy ryzyka oraz jego ocena.

Metodologia: W ramach badań przeprowadzonych na potrzeby artykułu dokonano przeglądu aktów prawnych i dostępnych wytycznych, przeanalizowano dostępne raporty o bezpieczeństwie i zawarte w nich dane dotyczące reprezentatywnych scenariuszy awaryjnych w 18 zakładach o dużym ryzyku wystąpienia poważnej awarii przemysłowej w województwie mazowieckim.

Wnioski: Krajowy system planowania i zagospodarowania przestrzennego nie uwzględnia w dostatecznym zakresie założeń doktryny zapobiegania poważnym awariom przemysłowym. Nie istnieje określona metodyka dokonywania oceny ryzyka, z racji czego poszczególne oceny ryzyka w raportach o bezpieczeństwie oparte są na niejednolitych zasadach, co w przypadku podobnych zakładów powoduje rozbieżności. Brakuje standaryzacji wymagań w zakresie prezentacji wyników analiz i ocen ryzyka, a w szczególności zasięgów oddziaływania promieniowania cieplnego, nadciśnienia i toksyczności. W efekcie wyniki te są prezentowane wedle uznania, w sposób uniemożliwiający ich jednoznaczną interpretację. Bez wykorzystania określonego oprogramowania nie jest możliwa również dokładna interpolacja danych. Wyniki dokonanej w 2017 roku dla województwa mazowieckiego analizy zagrożeń wykazały, iż obszar objęty oddziaływaniem zakładów o dużym ryzyku wystąpienia poważnej awarii poza swoim terenem w województwie mazowieckim wynosi ok. 2300 ha. Istotnym problemem jest również brak krajowych wytycznych w zakresie ustalania bezpiecznej odległości na potrzeby planowania i zagospodarowania przestrzennego, który sprawia, że ww. obszar podlega określonym rodzajom zagospodarowania z pominięciem lub niedostatecznym uwzględnieniem informacji o oddziaływaniu poważnych awarii przemysłowych.

Słowa kluczowe: awaria przemysłowa, reprezentatywne zdarzenie awaryjne, bezpieczna odległość, planowanie przestrzenne Typ artykułu: artykuł przeglądowy
\end{abstract}

Przyjęty: 01.03.2018; Zrecenzowany: 20.11.2018; Zatwierdzony: 22.11.2018;

Procentowy wkład merytoryczny: W. Wiśniewski - 45\%; G. Sobieszek - 45\%; B. Połeć - 10\%;

Identyfikatory ORCID autorów: W. Wiśniewski - 0000-0002-9106-5306; G. Sobieszek 0000-0001-9341-0743; B. Połeć - 0000-0003-2054-8068;

Proszę cytować: BiTP Vol. 51 Issue 3, 2018, pp. 150-169, doi: 10.12845/bitp.51.3.2018.11;

Artykuł udostępniany na licencji CC BY-SA 4.0 (https://creativecommons.org/licenses/by-sa/4.0/).

\section{ABSTRACT}

Aim: The aim of this paper is to assess the state of implementation in Poland of the current doctrine for the prevention of major industrial accidents in the context of providing safety distance in the process of shaping the spatial order.

Introduction: The obligation to perform an analysis and assessment of the risk of a major industrial accident lies above all with operators of upper-tier establishments. The security reports for such establishments contain detailed assumptions and the description of the analytical evaluation and risk assessment process and present its results together with their graphical visualisation. One of the most important elements of such a risk assessment 
is the identification of representative emergency events developed in representative emergency scenarios. The end value of the risk analysis and its evaluation depends on the degree of their accuracy and relevance for the type of establishment and industrial process parameters.

Methodology: The research conducted for the purposes of this article included a review of the legislation and available guidelines, an analysis of safety reports and data contained in them on representative emergency scenarios in 18 establishments with a high risk of a major industrial accident in the Mazowieckie Voivodeship.

Conclusions: The national land use and spatial planning system does not take into account the assumptions of the doctrine of prevention of major industrial accidents. There is no specific risk assessment methodology, resulting in individual risk assessments in safety reports being based on non-uniform rules, and thereby discrepancies between similar establishments. There is a lack of standardisation of requirements regarding the presentation of analysis results and risk assessments, in particular with regard to the ranges of thermal radiation, overpressure and toxicity. As a result, these results are presented arbitrarily in a way that prevents their clear interpretation. The exact interpolation of data is impossible without the use of specific software. The results of the risk analysis performed in 2017 for the Mazowieckie Voivodeship showed that the area affected by the upper-tier establishments with a high risk of a major accident outside of their territory in the Mazowieckie Voivodeship is approx. 2,300 ha. An important problem is also the lack of national guidelines for establishing safety distances for land use and spatial planning purposes, which means that the above-mentioned area is subject to certain types of land use, disregarding or providing insufficient attention to information on the impact of major industrial accidents. Keywords: major industrial accident, representative emergency scenario, safety distance, land use and spatial planning Type of article: review article

Received: 01.03.2018; Reviewed: 20.11.2018; Accepted: 22.11.2018;

Percentage contribution: W. Wiśniewski - 45\%; G. Sobieszek - 45\%; B. Połeć - 10\%;

Authors' ORCID IDs: W. Wiśniewski - 0000-0002-9106-5306; G. Sobieszek 0000-0001-9341-0743; B. Połeć - 0000-0003-2054-8068;

Please cite as: BiTP Vol. 51 Issue 3, 2018, pp. 150-169, doi: 10.12845/bitp.51.3.2018.11;

This is an open access article under the CC BY-SA 4.0 license (https://creativecommons.org/licenses/by-sa/4.0/).

\begin{abstract}
АННОТАЦИЯ
Цель: Цель данной статьи - оценка состояния внедрения в Польше действующей доктрины относительно предотвращения крупных промышленных аварий в контексте обеспечения безопасного расстояния в процессе формирования пространственного порядка.

Введение: Владельцы предприятий с высоким риском серьезной промышленной аварии обязаны проводить такой анализ риска и его оценку. Отчеты по безопасности для таких предприятий включают подробные предположения и описание процесса анализа и оценки риска, а также результаты, представленные также в графической форме. Одним из наиболее важных элементов этого процесса является выделение репрезентативных аварийных событий, рассматриваемых в репрезентативных аварийных сценариях. От степени их точности и соответствия данному типу установки и параметрам производственного процесса, зависит конечное значение анализа рисков и его оценка. Методология: В рамках исследования, проведенного для целей данной статьи, были проанализированы правовые акты и имеющиеся руководящие принципы, проанализированы имеющиеся отчеты по безопасности и содержащиеся в них данные о репрезентативных сценариях чрезвычайных ситуаций на 18 предприятиях с высоким риском крупной промышленной аварии в Мазовецком воеводстве.

Выводы: Национальная система пространственного планирования и развития не учитывает в соответствующей мере доктрину предотвращения серьезных промышленных аварий. Нет конкретной методологии оценки риска, из-за чего индивидуальные оценки риска в отчетах по безопасности основаны на неоднородных правилах, которые в случае аналогичных установок вызывают расхождения. Отсутствует стандартизация требований в отношении представления результатов анализа и оценки рисков, в частности диапазонов теплового излучения, гипертонии и токсичности. В результате эти результаты представляются на личное усмотрение, таким образом, получение однозначной интерпретации не представляется возможным. Точная интерполяция данных невозможна без использования специального программного обеспечения. Результаты анализа рисков, проведенного в 2017 году для Мазовецкого воеводства, показали, что площадь воздействия предприятий с высоким риском крупной аварии за пределами их территории в Мазовецком воеводстве, составляет около 2300 га. Важной проблемой также является отсутствие национальных руководств по установлению безопасного расстояния для планирования и пространственного обустройства, что приводит к тому, что вышеуказанный район подвержен особым типам планирования, в которых отсутствует или недостаточно учитывается информация о воздействии крупных промышленных аварий.

Ключевые слова: промышленная авария, репрезентативное аварийное событие, безопасное расстояние, пространственное планирование Тип статьи: обзорная статья
\end{abstract}

Принята: 01.03.2018; Рецензирована: 20.11.2018; Одобрена: 22.11.2018;

Процентное соотношение участия в подготовке статьи: W. Wiśniewski - 45\%; G. Sobieszek - 45\%; B. Połeć - 10\%;

Идентификаторы ORCID авторов: W. Wiśniewski - 0000-0002-9106-5306; G. Sobieszek 0000-0001-9341-0743; B. Połeć - 0000-0003-2054-8068;

Просим ссылаться на статью следующим образом: BiTP Vol. 51 Issue 3, 2018, pp. 150-169, doi: 10.12845/bitp.51.3.2018.11;

Настоящая статья находится в открытом доступе и распространяется в соответствии с лицензией CC BY-SA 4.0 (https://creativecommons.org/ licenses/by-sa/4.0/).

\section{Wprowadzenie}

Globalizacja przepływu ludzi, technologii oraz usług sprawiła, iż mówimy o obecnym świecie jak o "globalnej wiosce". Podstawą każdej dużej gospodarki światowej jest bez wątpienia przemysł ciężki, a w szczególności przemysł chemiczny

\section{Background}

The global freedom of movement of people, technologies and services has led to the world's becoming a global village. Clearly, the foundation of every world economy with a global reach is heavy industry, particularly chemical and petrochemical. To 
i petrochemiczny. Aby mogły powstać wystarczające ilości podstawowych surowców do produkcji paliw, tworzyw sztucznych, preparatów kosmetycznych czy nawozów konieczna jest budowa dużych zakładów przemysłowych i baz magazynowych pewnych substancji, które w świetle posiadanych właściwości fizykochemicznych są uznawane za niebezpieczne. Na poziomie międzynarodowym, jak i europejskim wprowadzono systemy klasyfikacji substancji niebezpiecznych, tj. Globalny Zharmonizowany System Klasyfikacji i Znakowania Chemikaliów (GHS) [6] opracowany w ramach Organizacji Narodów Zjednoczonych (ONZ) oraz rozporządzenie Parlamentu Europejskiego i Rady (WE) nr 1272/2008 z dnia 16 grudnia 2008 r. w sprawie klasyfikacji, oznakowania i pakowania substancji i mieszanin (CLP) [7], które stanowi implementację w Unii Europejskiej (UE) systemu GHS.

Przetwarzanie i magazynowanie dużych ilości substancji niebezpiecznych od zawsze stanowiło źródło zagrożeń dla zdrowia i życia ludzi, mienia oraz środowiska naturalnego. Poważne awarie, począwszy od wybuchu cykloheksanu w zakładzie Nypro Limited w miejscowości Flixborough w Wielkiej Brytanii (1974), uwolnienia TCDD w zakładzie ICMESA (Roche Group) w miejscowości Seveso we Włoszech (1976), uwolnienia izocyjanianu metylu w postaci gazu z fabryki pestycydów firmy Union Carbide w miejscowości Bhopal w Indiach (1994), aż po katastrofy współczesne, takie jak wybuch chmury gazowej (VCE) w rafinerii BP w Texas City w USA (2005), pożar zbiorników magazynowych w Bouncefield w Wielkiej Brytanii (2005) czy wyciek ropy na platformie Deepwater Horizon w Zatoce Meksykańskiej (2010) dość jednoznacznie obrazują potencjał zagrożeń związanych z substancjami niebezpiecznymi.

W perspektywie europejskiej odpowiedzią na nagły wzrost ryzyka wystąpienia awarii w zakładach przemysłowych było opracowanie i wdrożenie tzw. dyrektyw Seveso, począwszy od Seveso I (1982) [3], Seveso II $(1996,2003)$ [4] na Seveso III (2012) [5] kończąc.

W Polsce również funkcjonują zakłady przemysłowe, które wykorzystują do produkcji lub magazynują duże ilości substancji niebezpiecznych. Krajowe regulacje prawne w tym zakresie zawierają się w kolejnych nowelizacjach ustawy - Prawo ochrony środowiska [2].

Prowadzący zakłady o dużym ryzyku wystąpienia poważnej awarii przemysłowej [2], zgodnie z wymogami ustawy - Prawo ochrony środowiska, są zobowiązani do sporządzania raportu o bezpieczeństwie. Jednym z podstawowych elementów tego raportu jest opis zidentyfikowanych zagrożeń i oceny ryzyka wystąpienia poważnej awarii oraz informacje o środkach koniecznych do zapobiegania awariom.

Mnogość możliwych do wystąpienia zdarzeń awaryjnych w tego typu zakładach powoduje konieczność ich grupowania, w celu wyłonienia zbioru zdarzeń reprezentatywnych. Zdarzenia te, nazywane reprezentatywnymi zdarzeniami awaryjnymi (RZA), stanowią punkt wyjścia do dalszej analizy ryzyka wystąpienia poważnej awarii przemysłowej. Dla każdego z takich zdarzeń sporządzany jest opis jego przebiegu, czyli scenariusz. Definiuje on anatomię lub mechanizm powstawania awarii/wypadku, obrazując przewidywaną sekwencję zdarzeń, prowadzącą od przyczyn do niepożądanych skutków. supply sufficient amounts of basic raw materials to produce fuels, plastics, cosmetic preparations and fertilisers, it is necessary to build large industrial establishments and warehouse complexes for certain substances with hazardous physical and chemical characteristics. Hazardous substance classification systems were introduced at both international and European levels. These include the Global Harmonized System of Classification and Labelling (GHS) [6] developed by the United Nations and the Regulation (EC) No 1272/2008 of the European Parliament and of the Council of 16 December 2008 on classification, labelling and packaging of substances and mixtures, (CLP) [7], which is an EU implementation of the GHS system.

The processing and storage of large amounts of hazardous substances has always been a source of hazard for the health and lives of people, property and the natural environment. Serious accidents, from the cyclohexane explosion at Nypro Limited in the UK town of Flixborough (1974), the release of TCDD from an ICMESA (Roche Group) plant in Seveso, Italy (1976), and the release of methyl isocyanate gas from a Union Carbide pesticide factory in Bhopal, India (1994), to more recent disasters, such as the vapour cloud explosion (VCE) in a BP refinery in Texas City, USA (2005), the fire of oil storage containers in Bouncefield, UK (2005), or the Deepwater Horizon oil spill in the Gulf of Mexico (2010) leave no doubt as to the dangers involved in the processing of hazardous substances.

The European response to the sudden increase in the risk of industrial accidents was the preparation and implementation of the so-called Seveso Directives - Seveso I (1982) [3], Seveso II $(1996,2003)$ [4] and Seveso III (2012) [5].

Poland is also home to industrial plants which process or store substantial amounts of hazardous substances. The country's legal regulations in this respect are contained in the successive amendments to the act on the Environmental Protection Law [2].

As per the requirements of the Environmental Protection Law, entities managing upper-tier establishments which have a high risk of serious industrial accidents [2] are obliged to prepare safety reports. The basic elements of this report include a description of the identified hazards, an assessment of the risk of serious accidents and information about the measures necessary to prevent them.

The multitude of potential industrial accidents which can occur in such establishments makes it necessary to group them in order to create a set of representative accidents. Such events, called representative accidents (RA), are a starting point a the further analysis of the risk of a serious industrial accident. Every such event is described in terms of its course, i.e. a scenario is prepared for it. It defines the "anatomy" or mechanism of the failure/accident, representing the projected sequence of events leading from the causes to undesired consequences. 


\section{Podstawowe akty prawne regulujące obszar poważnych awarii przemysłowych oraz bezpiecznych odległości}

Najważniejszym, i w gruncie rzeczy jedynym aktem prawnym, formułującym krajową doktrynę zapobiegania poważnym awariom przemysłowym, jest ustawa z dnia 27 kwietnia $2001 \mathrm{r}$. Prawo ochrony środowiska (t.j. Dz. U. z 2018 r., poz. 799 ze zm.). Zawiera ona zarówno szczegółowe wytyczne dla prowadzących zakłady, które stwarzają ryzyko wystąpienia poważnej awarii przemysłowej, jak i dla organów administracji publicznej. W aktach wykonawczych do ww. ustawy sprecyzowane są natomiast wymagania formalne i merytoryczne dotyczące zasad klasyfikacji substancji, kwalifikacji zakładu oraz sporządzania dokumentacji. Jednocześnie ustawa ta w art. 73 określa uwarunkowania położenia zakładów stwarzających ryzyko wystąpienia awarii z uwzględnieniem konieczności zachowania ładu w obszarze planowania i zagospodarowania przestrzennego. Poszczególne zapisy tego artykułu, co prawda odnoszą się do różnych sytuacji formalnoprawnych zakładu (zakład istniejący, nowo projektowany, rozbudowujący się), jednakże posługują się ogólnikowymi stwierdzeniami w zakresie zapewnienia bezpieczeństwa i uwzględnienia zagrożeń w procesie planistycznym. Mowa tu w szczególności o tzw. bezpiecznej odległości. Brak ujęcia w ustawie jej definicji tworzy próżnię w przedmiocie jej stosowania. Ponadto podnoszona wielokrotnie konieczność zachowania bezpiecznej odległości nie znajduje jak dotąd kontynuacji, poza zapisem art. 73a, który określa, iż minister właściwy do spraw środowiska w porozumieniu z ministrem właściwym do spraw wewnętrznych i ministrem właściwym do spraw budownictwa, lokalnego planowania i zagospodarowania przestrzennego oraz mieszkalnictwa określi, w drodze rozporządzenia, sposób ustalania bezpiecznej odległości, rodzaje poważnych awarii przemysłowych, których potencjalne skutki należy uwzględnić przy ustalaniu bezpiecznej odległości oraz parametry graniczne oddziaływania potencjalnych skutków poważnych awarii przemysłowych w zakresie palności, wybuchowości i toksyczności substancji niebezpiecznych, których miejsca występowania należy uwzględnić przy ustalaniu bezpiecznej odległości.

Regulacje prawne w przedmiocie kształtowania ładu przestrzennego są zawarte w ustawie z dnia 27 marca 2003 r. o planowaniu i zagospodarowaniu przestrzennym (t.j. Dz. U. z 2018 r. poz. 1945). Co do kierunku zapisy te są zbieżne z treścią art. 73 ustawy prawo ochrony środowiska. Odnoszą się jednak w sposób władczy, wskazując organy administracji (Państwowa Straż Pożarna, Inspekcja Ochrony Środowiska), które biorąc udział w procesie kształtowania ładu przestrzennego, zajmują stanowisko w zakresie przeznaczenia przestrzeni w sąsiedztwie zakładu, jak i dopuszczenia lokalizacji nowego zakładu w już ukształtowanej relacji przestrzennej.

\section{Skrócona charakterystyka województwa mazowieckiego}

Województwo mazowieckie położone jest na obszarze Niziny Mazowieckiej nad rzeką Wisłą. Średnia wysokość

\section{The core legislation for serious industrial accidents and safety distances}

The most important and, in fact, the only piece of legislation formulating the national doctrine of preventing major industrial accidents is the Act of 27 April 2001, Environmental Protection Law (consolidated text, Journal Of Laws of 2018, item 799, as amended). It contains detailed guidelines both for the managers of establishments with a risk of major industrial accident and public administration bodies. The secondary legislation to this Act specifies the formal and technical requirements regarding the rules for classifying substances, qualifying establishments and preparing documentation. At the same time, Art. 73 of this Act specifies the conditions for locating establishments with a risk of industrial accidents taking into account the need to maintain order in terms of land use and spatial planning. The specific provisions of this article, while covering various formal and legal situations at an establishment (existing, newly designed, expanding establishment), use broad statements in referring to the issue of ensuring safety and taking hazards into account in the planning process. This is primarily the case with regard to the maintenance of safety distance. The fact that there is no definition of safety distance in the Act leads to the lack of its application. In addition, the need to maintain safety distance, already postulated numerous times, has not been further legislated, except for Article 73a, which provides that the minister in charge of the environment in agreement with the minister in charge of internal affairs and the minister in charge of construction, local planning, zoning and housing policy shall define, by way of a regulation, the method of defining safety distance and the types of major industrial accidents the potential consequences of which should be taken into account in determining safety distance and the threshold parameters of impact of the potential consequences of major industrial accidents in terms of flammability, explosiveness and toxicity of hazardous substances whose placement must be considered when defining safety distance.

The legal regulations on spatial governance are contained in the Act of 27 March 2003 on Land Use and Spatial Planning (consolidated text, Journal of Laws of 2018, item 1945). These provisions essentially correspond to the contents of Article 73 of the Environmental Protection Law. However, they refer to authority, indicating the administrative bodies (State Fire Service, Inspectorate of Environmental Protection) which, as participants in the process of spatial governance, take a stand on specifying the intended purpose of spaces adjoining industrial establishments and the approval of the location of a new establishment in an already developed spatial relations.

\section{Brief overview of the Mazowieckie Voivodeship}

The Mazowieckie Voivodeship is located in the area of the Mazovian Lowland on the Vistula River. The average elevation 
terenu waha się od 90 do 120 m n.p.m. Zlokalizowane jest między $1^{\circ} 153^{\prime} 33^{\prime \prime}$ a $23^{\circ} 07^{\prime} 42^{\prime \prime} \mathrm{dt}$. geogr. wschodniej a $51^{\circ} 00^{\prime} 48^{\prime \prime}$ a $53^{\circ} 28^{\prime} 54^{\prime \prime}$ szer. geogr. północnej. W centrum Niziny znajduje się Kotlina Warszawska, którą otaczają wyniesione do $230 \mathrm{~m}$ wysoczyzny. Przeważają płaskie lub lekko faliste równiny moreny dennej. W niektórych miejscach występują wzgórza moren czołowych oraz głęboko wcięte doliny rzeczne. Długość granic z sąsiednimi województwami wynosi z warmińsko-mazurskim: $218 \mathrm{~km}$, z podlaskim: $358 \mathrm{~km}$, z lubelskim: $372 \mathrm{~km}$, ze świętokrzyskim: 203 km, z tódzkim: 323 km, z kujawsko-pomorskim: $195 \mathrm{~km}$. Łączna długość granic województwa wynosi 1669 km. Powierzchnia województwa wynosi $35558,47 \mathrm{~km}^{2}$, co stanowi $11,4 \%$ obszaru Polski. Województwo mazowieckie jest w chwili obecnej największym terytorialnie województwem w Polsce. Województwo liczy ogółem 5349114 (13,91\% ludności kraju) mieszkańców, w tym w Warszawie 1748920 (ok. 32,7\% ludności województwa). Średnia gęstość zaludnienia województwa wynosi 150,4osób/km², w Warszawie 3381 osób/km². Ludność województwa mieszka w większości w 85 miastach - 64,28\% ludności województwa [9, 18].

Zgodnie z podziałem administracyjnym kraju, obowiązującym od 1 stycznia 1999 r. i zmienionym w 2002 r., w woj. mazowieckim wydzielono 5 miast na prawach powiatu, w tym Warszawę i 4 tzw. powiaty grodzkie Płock, Radom, Siedlce, Ostrołękę oraz 37 powiatów ziemskich. Obszar województwa podzielony jest obecnie na 314 gmin, w tym 35 miejskich, 50 miejsko-wiejskich i 229 wiejskich. Około $17 \%$ całej powierzchni województwa stanowią tereny zurbanizowane, pozostałą część stanowią użytki rolne oraz lasy. Zabudowa zwarta dominuje w aglomeracjach miejskich [18].

Mazowsze z racji centralnego położenia oraz lokalizacji miasta stołecznego Warszawy stanowi dogodny obszar do lokalizowania obiektów przemysłowych. Największy obszar przemysłowy, tj. teren zakładu produkcyjnego PKN ORLEN S.A. w Płocku, jest zlokalizowany w granicach administracyjnych miasta Płock.

Uchwałą nr 180/14 z dnia 7 lipca 2014 r. Sejmik Województwa Mazowieckiego przyjął Plan Zagospodarowania Przestrzennego Województwa Mazowieckiego (Dz. Urz. z dnia 15 lipca 2014 r. poz. 6868). W powyższym planie ujęto tematykę z zakresu zagrożenia poważnymi awariami przemysłowymi.

\section{Zakłady o dużym ryzyku wystąpienia poważnej awarii przemysłowej w Polsce i na Mazowszu}

Według danych Głównego Inspektoratu Ochrony Środowiska [20] na dzień 31 grudnia 2015 r. w całym kraju zewidencjonowane zostały 182 zakłady o dużym ryzyku wystąpienia poważnej awarii przemysłowej (ZoDR). Liczbę zakładów ZoDR w podziale na województwa przedstawia ryc. 1. is between 90 and 120 metres (above sea level). It is located between $19^{\circ} 15^{\prime} 33^{\prime \prime}$ and $23^{\circ} 07^{\prime} 42^{\prime \prime} \mathrm{E}$ and between $51^{\circ} 00^{\prime} 48^{\prime \prime}$ and $53^{\circ} 28^{\prime} 54^{\prime \prime} \mathrm{N}$. In the middle of the Lowland stretches the Warsaw Basin, which is surrounded by uplands with elevations up to $230 \mathrm{~m}$. The land is dominated by flat or slightly waved plains of a ground moraine. Some locations feature terminal moraine hills and steep river valleys. The length of the boundaries with the neighbouring voivodeships is as follows: Warmińsko-Mazurskie 218 km, Podlaskie: 358 km, Lubelskie: 372 km, Świętokrzyskie: 203 km, Łódzkie 323 km, Kujawsko-Pomorskie 195 km. The total length of the voivodeship's boundaries is $1,669 \mathrm{~km}$. The Mazowickie Voivodeship's area is $35,558.47 \mathrm{~km}^{2}$, which is $11.4 \%$ of the total area of Poland. It is currently the largest voivodeship in Poland in terms of area. The voivodeship has a population of $5,349,114$ (13.91\% of Poland's population), of which 1,748,920 people live in Warsaw (approx. $32.7 \%$ of the voivodeship's population). The average population density is 150.4 per $\mathrm{km}^{2}$, in Warsaw $-3,381$ per $\mathrm{km}^{2}$. Most residents of the Mazovian Voivodeship live in its 85 cities and towns, which are home to $64.28 \%$ of the population $[9,18]$.

In accordance with the country's administrative division in force since 1 January 1999 and amended in 2002, the Mazowieckie Voivodeship has 5 cities with district rights, including Warsaw, 4 townships - Płock, Radom, Siedlce, Ostrołęka and 37 country districts. The area of the voivodeship is currently divided into 314 communes, including 35 urban communes, 50 urban-rural communes and 229 rural communes. About $17 \%$ of the voivodeship's area is covered by urbanised areas and the remaining part is largely comprised of agricultural land and forests. High-density development dominates in agglomerations [18].

Due to its central location and the presence of Poland's capital city (Warsaw), the Mazowieckie Voivodeship is a convenient location for industrial establishments. The largest industrialised area, i.e. the area of the PLN ORLEN S.A. industrial plant in Płock, is located within the administrative borders of Płock.

Pursuant to Resolution No 180/14 of 7 July 2014, the Parliament of the Mazowieckie Voivodeship adopted the Master Zoning Plan for the Mazowieckie Voivodeship (Journal of Laws of 15 July 2014 , item 6868 ). This plan included a discussion of issues connected with major industrial accidents.

\section{Upper-tier establishments in Poland and the Mazowieckie Voivodeship}

According to data from the Chief Inspectorate of Environmental Protection [20], as at 31 December 2015, there were 182 identified upper-tier establishments (UTE) in Poland. Fig. 1 presents the number of UTE divided into voivodeships . 


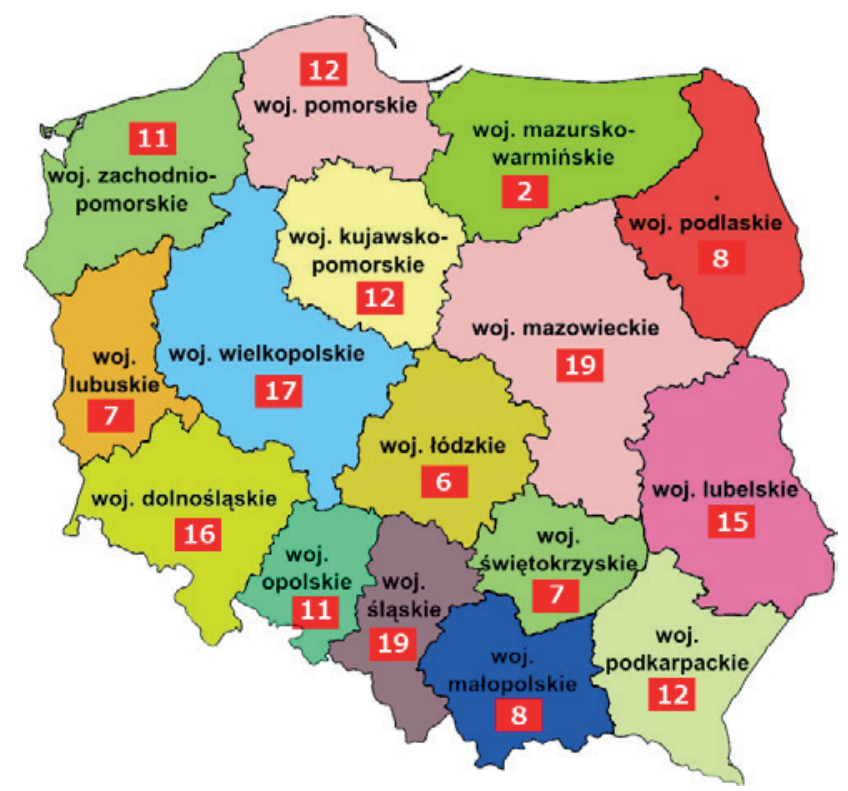

Rycina 1. Liczba zakładów ZoDR w układzie województw - stan na dzień 3 czerwca 2015 r.

Figure 1. Number of upper-tier establishments per voivodeship - as at 3 June 2015

Źródło: Opracowanie własne na podstawie [20]

Source: Own elaboration based on [20]

Na terenie województwa mazowieckiego na przestrzeni lat 2006-2017 liczba zakładów o dużym ryzyku (ZoDR) kształtowała się następująco:
The number of upper-tier establishments (UTE) in the Mazowieckie Voivodeshi p in the years 2006-2017 was as follows:

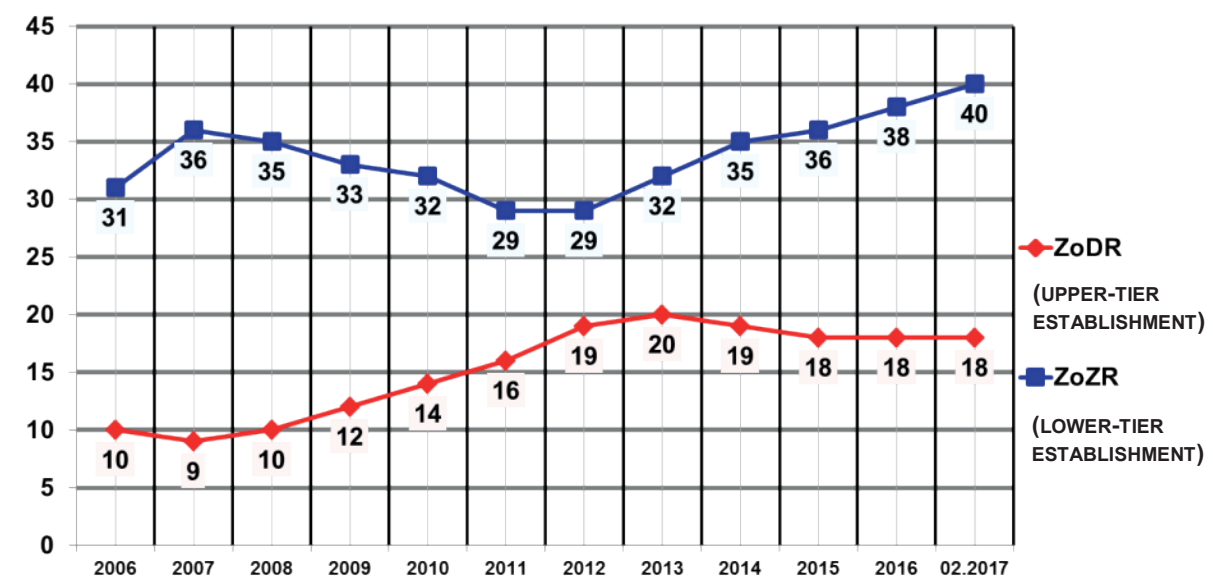

Rycina 2. Zestawienie liczby zakładów „sevesowskich" na terenie Mazowsza w latach 2006-2017

Figure 2. The number of "Seveso" establishments in Mazovia in 2006-2017

Źródło: Opracowanie własne na podstawie [18]

Source: Own elaboration based on [18].

Zgodnie z powyższym, wg stanu na miesiąc lipiec $2017 \mathrm{r}$., na terenie Mazowsza było zlokalizowanych 18 zakładów o dużym ryzyku wystąpienia poważnej awarii przemysłowej. Rozmieszczenie poszczególnych zakładów w układzie województwa przedstawiono na ryc. 3 .
As per the above data, as at July 2017, 18 upper-tier establishments were located in the Mazowieckie Voivodeship. Fig. 3 presents the locations of individual establishments in the voivodeship. 


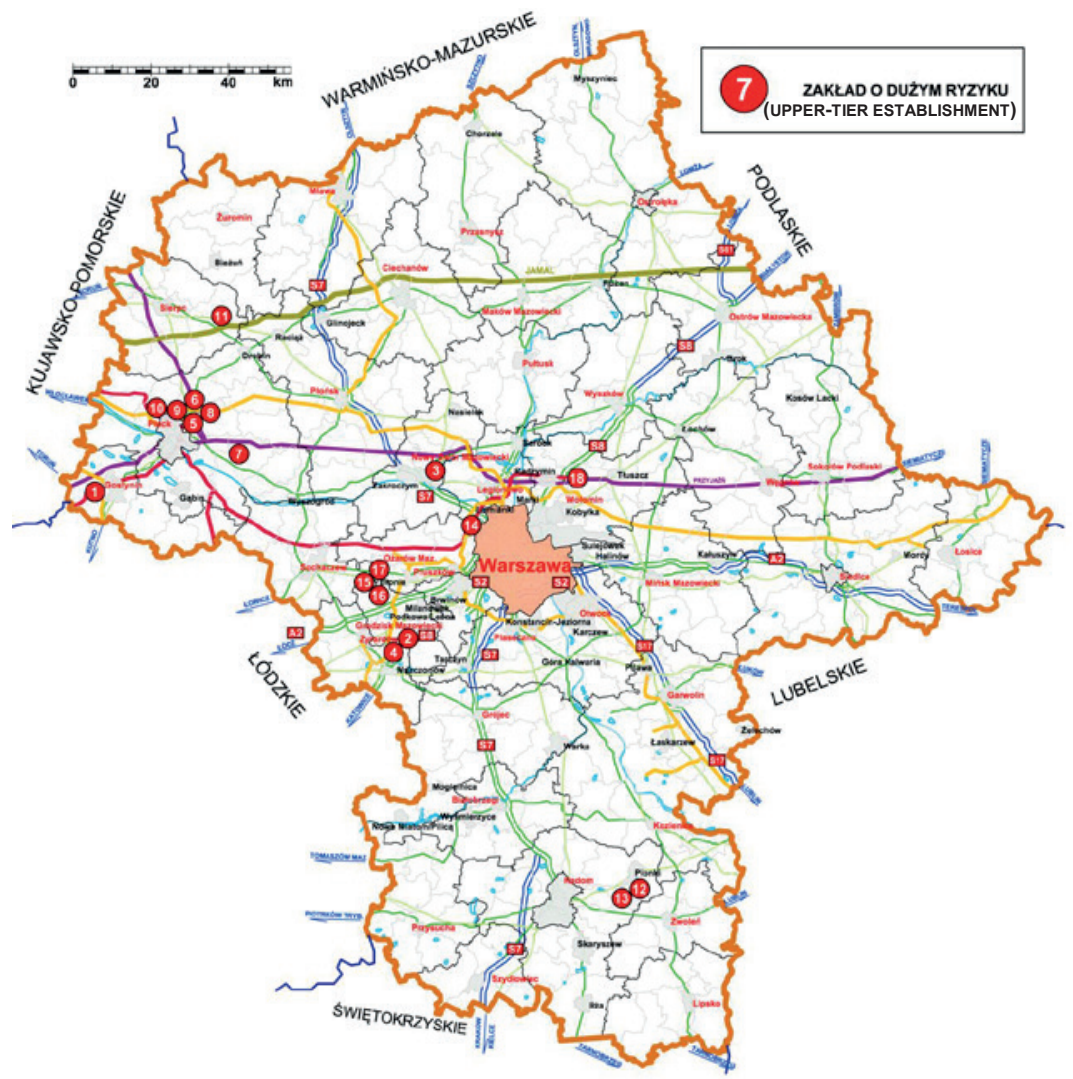

Rycina 3. Lokalizacja zakładów o dużym ryzyku na terenie województwa mazowieckiego

Figure 3. Location of upper-tier establishments in the Mazowieckie Voivodeship

Źródło: Opracowanie własne na podstawie [18]

Source: Own elaboration based on [18]

Analiza profilu ich działalności wykazała przede wszystkim, że najwięcej jest zakładów, w których magazynowane są i dystrybuowane środki ochrony roślin, aerozole, środki toksyczne (w opakowaniach jednostkowych i zbiorczych). W tabeli 1 dokonano zestawienia profili działalności zakładów o dużym ryzyku wystąpienia poważnej awarii przemysłowej.
A business profile analysis showed the prevalence of establishments which store and distribute pesticides, aerosols, toxic agents (in unit and bulk packaging). Table 1 lists the business profiles of upper-tier establishments.

Tabela 1. Zestawienie profili działalności zakładów o dużym ryzyku.

Table 1. Summary of the business profiles of upper-tier establishments.

\begin{tabular}{|c|c|c|}
\hline $\begin{array}{l}\text { Lp./ } \\
\text { No. }\end{array}$ & Profile działalności zakładów ZDR (wiodące)/Business profiles of (leading) upper-tier establishments & $\begin{array}{l}\text { Liczba zakładów } \\
\text { /Number of establishments }\end{array}$ \\
\hline 1 & 2 & 3 \\
\hline 1 & Przemysł rafineryjny i petrochemiczny / refinery and petrochemical industry & 3 \\
\hline 2 & Produkcja pian (budownictwo) / manufacture of construction foams & 1 \\
\hline 3 & Produkcja środków czyszczących i piorących / manufacture of cleaning and washing agents & 1 \\
\hline 4 & $\begin{array}{l}\text { Magazynowanie i dystrybucja paliw płynnych (w tym paliwa lotniczego) / storage and distribution of liquid fuels (including } \\
\text { jet fuel) }\end{array}$ & 3 \\
\hline 5 & Magazynowanie i dystrybucja gazu płynnego / storage and distribution of liquid gas & 2 \\
\hline 6 & Magazynowanie surowej ropy naftowej / storage of crude oil & 1 \\
\hline 7 & Produkcja materiałów wybuchowych / manufacture of explosive materials & 1 \\
\hline 8 & $\begin{array}{c}\text { Magazynowanie i dystrybucja środków ochrony roślin, aerozoli, środków toksycznych (opakowania jednostkowe i zbiorcze) } \\
\text { / storage and distribution of pesticides, aerosols, toxic agents (unit and bulk packaging) }\end{array}$ & 5 \\
\hline 9 & Produkcja pasz / Manufacture of feedstuffs & 1 \\
\hline
\end{tabular}

Źródło: Opracowanie własne.

Source: Own elaboration. 
Przedmiotowa analiza profili działalności została przeprowadzona dla 18 zakładów o dużym ryzyku wystąpienia poważnej awarii przemysłowej [19], tj.:

1) Baza Paliw OLPP Sp. z o.o. nr 5 w Emilianowie, 05-205 Klembów;

2) PERN S.A. Baza w Miszewku Strzałkowskim, 09-472 Słupno;

3) Basell ORLEN Polyolefins Sp. z o.o., ul. Chemików 7, 09411 Płock;

4) Baza Magazynowa nr 101 Mościska PKN ORLEN S.A., 05-080 Izabelin, ul. Estrady 8;

5) MESKO S.A. w Skarżysku-Kamiennej Oddział w Pionkach, ul. Zakładowa 7, 26-670 Pionki;

6) Zakład Produkcyjny w Płocku Polskiego Koncernu Naftowego ORLEN S.A., ul. Chemików 7, 09-411 Płock;

7) Terminal Gazu Płynnego w Płocku Orlen Paliwa Sp. z o.o., 09-400 Płock, ul. Długa 1;

8) Raben Logistics Polska Spółka z o.o., ul. Chrzanowska 7, 05-825 Grodzisk Mazowiecki;

9) Centralny Magazyn Dystrybucyjny Bayer CropScience, Pass $20 \mathrm{H}, 05-870$ Błonie;

10) Soudal Manufacturing Sp. z o.o., ul. Wspólna 21, 26-670 Pionki;

11) Reckit Benckiser Production (Poland) Sp. z o.o., Fabryka w Nowym Dworze Mazowieckim, ul. Okunin 1, 05-100 Nowy Dwór Mazowiecki;

12) PCC Exol S.A., Wytwórnia Etoksylatów - Oksylakilatów, ul. Długa 14, 09-411 Płock;

13) FERTICO Sp. z o.o., ul. Bieniewicka $43,05-870$ Błonie;

14) Warter Fuels S.A. w Płocku, ul. Chemików 5, 09-411 Płock;

15) Wilshire Holding Sp. z o.o., Pass $20 \mathrm{~N}, 05-870$ Błonie;

16) Wytwórnia Pasz CEDROB PASZE w Raciążu, ul. Płocka 78, 09-140 Raciąż;

17) PPH MARK-GAZ, Rozlewnia Gostynin, 09-500 Gostynin, ul. Płocka 66/68;

18) Ekonip Spółka z.o.o., Radziejowice 96-325, ul. Przemysłowa 1 a.

\section{Etap tworzenia reprezentatywnych scenariuszy awaryjnych $\mathrm{w}$ procesie analizy i oceny ryzyka}

Wszelkie działania realizowane $\mathrm{w}$ obszarze zapobiegania poważnym awariom i ograniczaniu ich skutków poprzedzone są analizą i oceną ryzyka. Jedną z szeroko stosowanych w tym zakresie metod jest analiza warstw zabezpieczeń (AWZ), w której konieczne jest wcześniejsze wytypowanie scenariusza awaryjnego. W procesie oceny ryzyka wyróżnia się następujące etapy [14]:

1. Charakterystyka instalacji - zgromadzenie informacji o danej instalacji, substancjach, jakie się w niej znajdują oraz parametrach prowadzonego procesu.

2. Identyfikacja źródeł zagrożeń - określenie parametrów instalacji, substancji i procesu, które mogą powodować zagrożenie.
The business profile analysis was conducted for 18 upper-tier establishments [19], i.e.:

1) Fuel Depot of OLPP Sp. z o.o. No. 5 in Emilianów, 05-205 Klembów;

2) PERN S.A. Depot in Miszewku Strzałkowskim, 09-472 Słupno;

3) Basell ORLEN Polyolefins Sp. z o.o., ul. Chemików 7, 09-411 Płock;

4) Storage Complex No. 101 Mościska PKN ORLEN S.A., 05-080 Izabelin, ul. Estrady 8;

5) MESKO S.A. in Skarżysko-Kamienna, Branch in Pionki, ul. Zakładowa 7, 26-670 Pionki;

6) Production Plant in Płock of Polski Koncern Naftowy ORLEN S.A., ul. Chemików 7, 09-411 Płock;

7) Liquid Gas Terminal in Płock, Orlen Paliwa Sp. z o.o., 09-400 Płock, ul. Długa 1;

8) Raben Logistics Polska Spółka z o.o., ul. Chrzanowska 7, 05-825 Grodzisk Mazowiecki;

9) Central Distribution Warehouse Bayer CropScience, Pass $20 \mathrm{H}, 05-870$ Błonie;

10) Soudal Manufacturing Sp. z o.o., ul. Wspólna 21, 26-670 Pionki;

11) Reckit Benckiser Production (Poland) Sp. z o.o., Plant in Nowy Dwór Mazowiecki, ul. Okunin 1, 05-100 Nowy Dwór Mazowiecki;

12) PCC Exol S.A., Wytwórnia Etoksylatów - Oksylakilatów, ul. Długa 14, 09-411 Płock;

13) FERTICO Sp. z o.o., ul. Bieniewicka 43, 05-870 Błonie;

14) Warter Fuels S.A. in Płock, ul. Chemików 5, 09-411 Płock;

15) Wilshire Holding Sp. z o.o., Pass 20N, 05-870 Błonie;

16) Wytwórnia Pasz CEDROB PASZE w Raciążu, ul. Płocka 78, 09-140 Raciąż;

17) PPH MARK-GAZ, Rozlewnia Gostynin, 09-500 Gostynin, ul. Płocka 66/68:

18) Ekonip Spółka z.o.o., Radziejowice 96-325, ul. Przemysłowa 1a.

\section{The stage of creating representative accident scenarios in the process of risk analysis and assessment}

All measures for the prevention of major industrial accidents and the reduction of their impact are preceded by a risk analysis and assessment. One of the broadly used methods in this respect is the Layer of Protection Analysis (LOPA), which requires the early selection of an accident scenario. The following stages are distinguished in the process of risk assessment [14]:

1. Plant characteristics - collecting information about a specific plant, the substances processed in it and process parameters.

2. Hazard source identification - specifying the parameters of the plant, substances and processes which might cause hazards. 
3. Scenariusz awaryjny - dokonanie wyboru zdarzeń awaryjnych, wybór reprezentatywnych zdarzeń awaryjnych (RZA) i sporządzenie dla każdego RZA osobno modelu scenariusza awaryjnego.

4. Zintegrowana ocena ryzyka dla wszystkich scenariuszy reprezentatywnych zdarzeń awaryjnych.

Na ryc. 4 przedstawiono schemat zarządzania ryzykiem wystąpienia poważnej awarii przemysłowej, na którym wskazano etap tworzenia scenariuszy awaryjnych w procesie oceny ryzyka.
3. Accident scenario - selecting potential accidents, representative accidents (RA) and preparing a separate accident scenario model for each RA.

4. Integrated risk assessment for all representative accident scenarios.

Fig. 4 presents a diagram of risk management for major industrial accidents, indicating the stage of developing accident scenarios in the risk assessment process.
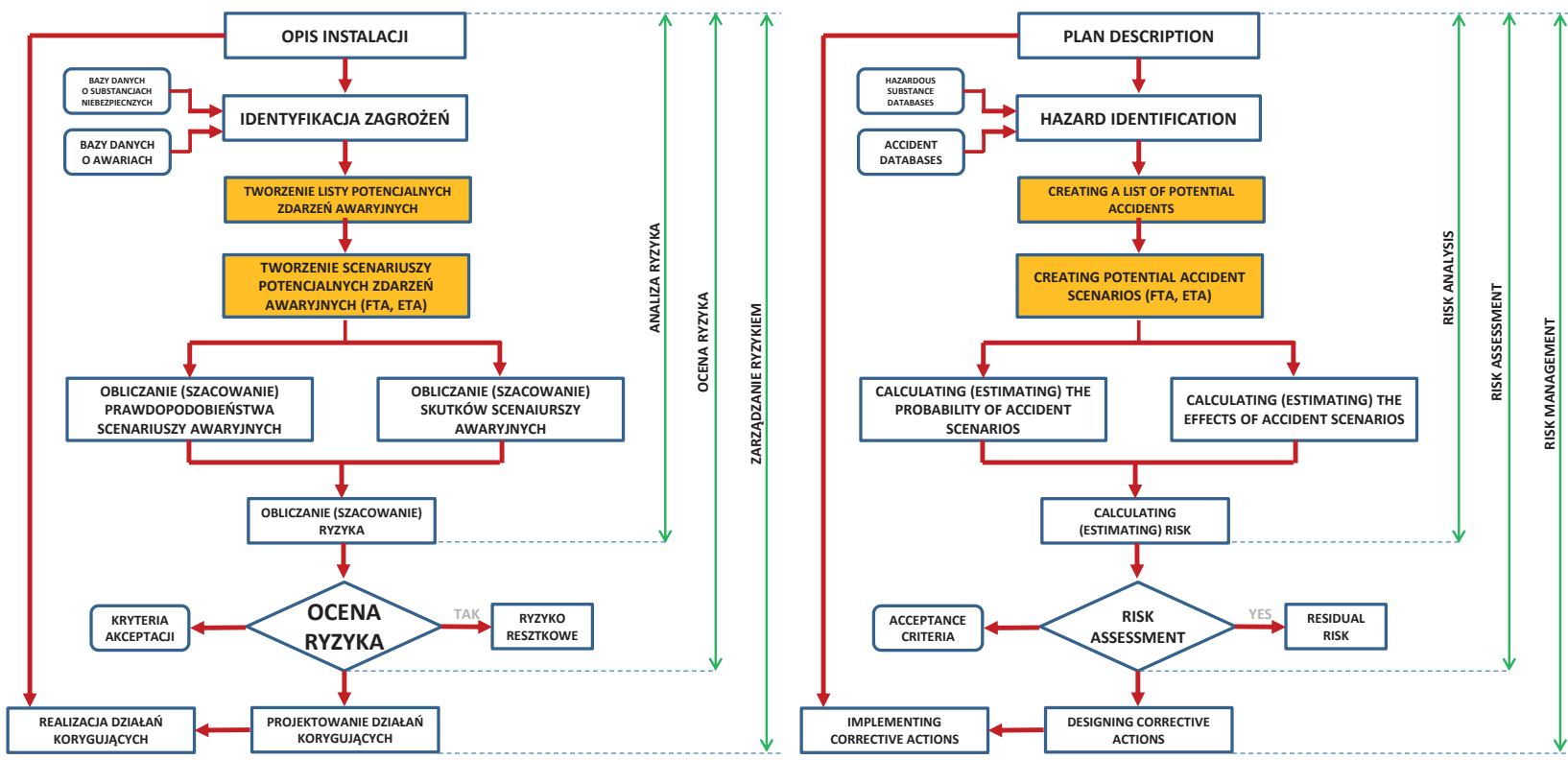

Rycina 4. Schemat zarządzania ryzykiem wystąpienia poważnych awarii przemysłowych

Figure 4. Risk management diagram for major industrial accidents

Źródło: Opracowanie własne na podstawie [14].

Source: Own elaboration based on [14].

Zdarzenia reprezentatywne to inaczej takie zdarzenia, które posiadają, każde w określonym obszarze, cechy charakterystyczne dla wybranej grupy zdarzeń podstawowych. Pozwalają one ograniczyć szybki i trudny do kontrolowania przyrost danych tworzonych w trakcie analizy ryzyka.

Każde zdarzenie ze zbioru RZA podlega rozwinięciu w reprezentatywny scenariusz awaryjny (RSA), rozumiany jako mechanizm powstawania ciągów zdarzeń awaryjnych, rozpoczynających się od zdarzeń inicjujących, aż do konkretnych skutków zagrożeń chemicznych [14].

Dobrze przygotowane scenariusze awaryjne dostarczają całościowych informacji o możliwości wystąpienia zdarzenia w instalacji chemicznej oraz jego spodziewanych skutków dla pracowników, ludności, majątku i środowiska naturalnego.

Poważne awarie podlegające analizie ryzyka są głównie źródłem trzech rodzajów zagrożeń:

- oddziaływania promieniowania cieplnego (gęstości strumienia ciepła);

- oddziaływania nadciśnienia;

- oddziaływania efektu toksycznego

Powyższym rodzajom zagrożeń przypisano wartości progowe ich oddziaływania oraz przewidywane skutki.
Representative accidents are such events that have, each in a specific area, the features distinctive for a selected group of underlying events. They reduce the fast and hard-to-control accumulation of data generated during risk analysis.

Each event in a set of RA is developed into a representative accident scenario (RAS), understood as the mechanism of development of potential accident series from initiating events to the specific consequences of chemical hazards [14].

Well-prepared accident scenarios provide comprehensive information on the possibility of accident occurrence in a chemical plant and the expected consequences for the personnel, public, property and natural environment.

Major accidents covered by risk analysis are mainly the source of three types of hazards:

- thermal radiation (heat flux density) hazard

- overpressure hazard;

- toxicity hazard.

The above types of hazards were assigned with their threshold impact values and their consequences. 
Tabela 2. Oddziaływanie promieniowania cieplnego na ludzi i sprzęt (elementy instalacji)

Table 2. Effects of thermal radiation on humans and equipment (plant elements)

\begin{tabular}{|c|c|c|}
\hline $\begin{array}{l}\text { Promieniowanie cieplne/ } \\
\text { Thermal radiation }\left[\mathrm{kW} / \mathrm{m}^{2}\right]\end{array}$ & Skutki dla sprzętu/Effects on equipment & Skutki dla ludzi/Effects on humans \\
\hline 1 & 2 & 3 \\
\hline 1,2 & - & $\begin{array}{l}\begin{array}{c}\text { Nie stwarza dyskomfortu przy długotrwałym narażeniu/No discomfort caused on } \\
\text { prolonged exposure }\end{array} \\
\text {. }\end{array}$ \\
\hline 2.1 & - & $\begin{array}{l}\text { Nie stwarza dyskomfortu przy długotrwałym narażeniu/Minimum value to cause } \\
\text { pain after 1-minute exposure }\end{array}$ \\
\hline $4^{\star}$ & $\begin{array}{l}\text { Uszkodzenie powierzchni z tworzyw } \\
\text { sztucznych i powłok lakierniczych/Damage to } \\
\text { plastic surfaces and coating. }\end{array}$ & $\begin{array}{c}\text { Powoduje ból przy narażeniu dłuższym niż } 20 \mathrm{~s} / \text { Causes pain following exposure } \\
\text { longer than } 20 \mathrm{~s}\end{array}$ \\
\hline $12,5^{\star \star}$ & $\begin{array}{l}\text { Topienie się rur z tworzywa sztucznego/Mel- } \\
\text { ting of plastic pipes }\end{array}$ & $\begin{array}{c}1 \% \text { ofiar śmiertelnych po } 1 \mathrm{~min} \text {. narażenia, oparzenia I stopnia po } 10 \mathrm{~s} \\
\text { narażenia/1\% fatalities following } 1 \text { minute exposure time, first-degree burns } \\
\text { following } 10 \mathrm{~s} \text { exposure }\end{array}$ \\
\hline 25 & $\begin{array}{l}\text { Topienie się rur z tworzywa sztucznego/ } \\
\text { Ignition of wood after very long exposure }\end{array}$ & $\begin{array}{l}100 \% \text { ofiar śmiertelnych po } 1 \mathrm{~min} \text {. narażenia, znaczne urazy po } 10 \mathrm{~s} \\
\text { narażenia/100\% fatalities following } 1 \text { minute exposure time, serious injuries after } \\
10 \text { seconds of exposure }\end{array}$ \\
\hline 37,5 & $\begin{array}{l}\text { Topienie się rur z tworzywa sztucznego/ } \\
\text { Damage to devices comprising the process } \\
\text { plant. }\end{array}$ & $\begin{array}{l}100 \% \text { ofiar śmiertelnych po } 1 \mathrm{~min} \text {. narażenia, } 1 \% \text { ofiar śmiertelnych po } 10 \mathrm{~s} \\
\text { narażenia/100\% fatalities following } 1 \text { minute exposure time, } 1 \% \text { fatalities following } \\
10 \mathrm{~s} \text { exposure }\end{array}$ \\
\hline \multicolumn{3}{|c|}{$\begin{array}{l}\text { * Przyjęte kryteria graniczne na potrzeby planowania i zagospodarowania przestrzennego / cut-off criteria for land use and spatial planning } \\
\text { ** Przyjęte kryteria graniczne wystąpienia efektu domino / cut-off criteria for domino effect }\end{array}$} \\
\hline \multicolumn{3}{|c|}{ Źródło: Opracowanie własne na podstawie [13, 14, 22]. } \\
\hline \multicolumn{3}{|c|}{ Source: Own elaboration based on $[13,14,22]$. } \\
\hline \multicolumn{3}{|c|}{ Tabela 3. Oddziaływanie nadciśnienia na ludzi } \\
\hline \multicolumn{3}{|c|}{ Table 3. Effects of overpressure on humans } \\
\hline Nadciśnienie/Overpressure & $\mathrm{kPa}]$ & Skutki/Effects \\
\hline 1 & & 2 \\
\hline $100-133$ & \multicolumn{2}{|c|}{$50 \%$ uszkodzenie błony bębenkowej ucha (u osób poniżej 20 roku życia) $/ 50 \%$ eardrum damage (in people under 20 years of age) } \\
\hline $200-233$ & \multicolumn{2}{|c|}{$\begin{array}{l}50 \% \text { uszkodzenie błony bębenkowej ucha (u osób powyżej } 20 \text { roku życia) } \\
50 \% \text { eardrum damage (in people over } 20 \text { years of age) }\end{array}$} \\
\hline $133-200$ & \multicolumn{2}{|r|}{ Znaczne uszkodzenia płuc/Major lung damage } \\
\hline $200-300$ & \multicolumn{2}{|c|}{ Graniczna wartość wystąpienia ofiar śmiertelnych/Cut-off value for fatalities } \\
\hline $350-500$ & \multicolumn{2}{|r|}{$50 \%$ ofiar śmiertelnych $/ 50 \%$ fatalities } \\
\hline $500-800$ & \multicolumn{2}{|r|}{$100 \%$ ofiar śmiertelnych/100\% fatalities } \\
\hline
\end{tabular}

Źródło: Opracowanie własne na podstawie [13, 14, 22].

Source: Own elaboration based on [13, 14, 22].

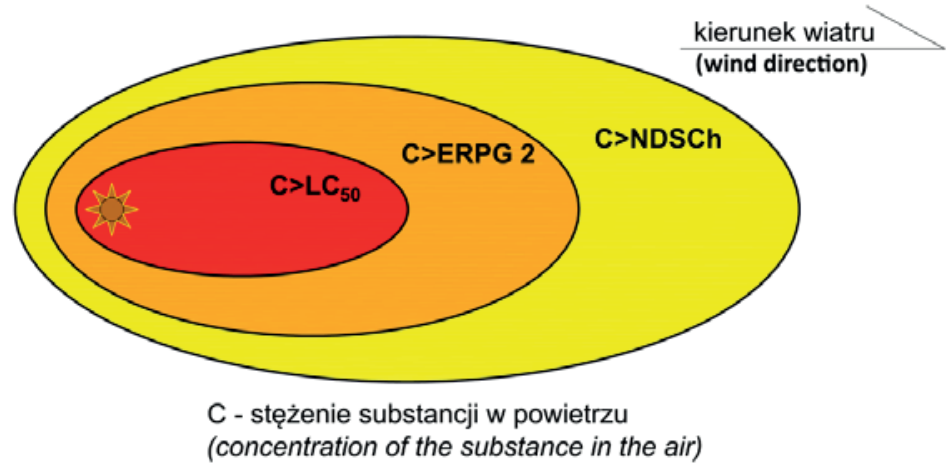

Rycina 5. Rozkład stref zagrożeń toksycznych

Figure 5. Distribution of toxic zones

Źródło: Opracowanie własne.

Source: Own elaboration. 
Tabela 4. Oddziaływanie nadciśnienia na budynki i instalacje.

Table 4. Effects of thermal radiation on buildings and installation elements

\begin{tabular}{|c|c|}
\hline $\begin{array}{l}\text { Nadciśnienie/ } \\
\text { Overpressure [kPa] }\end{array}$ & Skutki / Effects \\
\hline 1 & 2 \\
\hline 0,14 & Dokuczliwy hałas, szum (137 dB)/ Disturbing noise (137 dB) \\
\hline 0,21 & Pękanie dużych szyb okiennych (szkło okienne)/ Cracking of large window glass panes (window glass) \\
\hline 0,3 & Głośny huk (143 dB)/ Extremely loud noise (143 dB) \\
\hline 0,7 & Rozrywanie ram okiennych/ Fracturing window frames \\
\hline 2,7 & Wartość bezpieczna dla budynku/ Safe value for a building \\
\hline $2,8-3^{*}$ & Ograniczone uszkodzenia dla konstrukcji/ Limited structural damage \\
\hline 4,8 & Uszkodzenia konstrukcji budynku/ Structural damage \\
\hline 6,9 & Częściowe zburzenia budynków/ Partial destruction of buildings \\
\hline $6,9-13,8$ & $\begin{array}{l}\text { Zniszczenie płyt gipsowo - kartonowych, elementów stalowych i aluminiowych, uszkodzenie mocowań i posadowień elementów konstrukcyjnych/ } \\
\text { Destruction of gypsum plasterboards, steel and aluminium elements, damage to mountings and foundations of structural elements }\end{array}$ \\
\hline 9 & Lekkie odkształcenia ramowej konstrukcji budynku wykonanej ze stali/Slight deformations of the building's steel framework structure \\
\hline $13,8-14^{\star \star}$ & Częściowe zawalenie się ścian i dachów budynków/Partial collapse of walls and roofs of buildings \\
\hline $14-20,7$ & Rozpadanie się niewzmocnionych ścian betonowych/ The collapse of non-reinforced concrete walls \\
\hline 15,8 & Dolna granica nadciśnień poważnych uszkodzeń konstrukcji budowlanych \\
\hline 17,2 & Zburzenie $50 \%$ domów murowanych/Collapse of $50 \%$ of masonry buildings \\
\hline 20,7 & $\begin{array}{l}\text { Niewielkie uszkodzenia ciężkich maszyn i urządzeń (o masie do } 1500 \mathrm{~kg} \text { ), zniekształcenie i wyrwanie z posadowienia (fundamentu) } \\
\text { ramowych konstrukcji stalowych/ Minor damage to heavy machinery and equipment (weighing up to 1,500 kg), deformation and pulling } \\
\text { framework steel structures from the foundations }\end{array}$ \\
\hline $34,5-48,0$ & Prawie całkowite zniszczenie budynków/Nearly complete destruction of buildings \\
\hline 48 & Wywrócenie załadowanych wagonów towarowych/Overturning of freight wagons with cargo \\
\hline $48,0-55,1$ & $\begin{array}{l}\text { Zniszczenie ścian murowanych o grubości mniejszej o grubości mniejszej lub równej 0,3 m, wykonanych z cegły pełnej, zniszczenia } \\
\text { zbiorników magazynowych powodujących masowe wypływy substancji, granica wystąpienia efektu domino (oddziaływania destruktywnego } \\
\text { reprezentatywnego zdarzenia awaryjnego na sąsiednią instalacje lub obiekt)/Destruction of masonry walls with a thickness lower than or } \\
\text { equal to } 0.3 \mathrm{~m} \text {, made of full brick, destruction of storage containers causing massive substance spills, the threshold of the domino effect } \\
\text { (the destructive impact of a representative accident on the neighbouring plant or engineering structure) }\end{array}$ \\
\hline 62,1 & Całkowite zniszczenie załadowanych, krytych wagonów towarowych/ Complete destruction of covered freight wagons with cargo \\
\hline 68,9 & $\begin{array}{l}\text { Całkowite zniszczenie budynków, przesunięcie i poważne uszkodzenia ciężkich maszyn i urządzeń (o masie do } 3500 \mathrm{~kg} \text { )/ Complete } \\
\text { destruction of buildings, dislocation or major damage to heavy machinery and devices (weighing up to 3,500 kg) }\end{array}$ \\
\hline
\end{tabular}

Źródło: Opracowanie własne na podstawie [13, 14, 22].

Source: Own elaboration based on $[13,14,22]$

Warto w tym miejscu podkreślić, iż na szczeblu centralnym jak dotąd nie pojawiły się rekomendacje w zakresie:

- metodyki oceny ryzyka wystąpienia poważnych awarii przemysłowych,

- rodzajów poważnych awarii, jakie należy rozpatrywać w procesie analizy ryzyka,

- oprogramowania wykorzystywanego do modelowania skutków uwolnień substancji niebezpiecznych do otoczenia,

- oprogramowania lub metodyki obliczeń (szacowania) wartości prawdopodobieństwa wystąpienia awarii.

Oznacza to, iż każdorazowo autor dokumentacji decyduje o wyborze stosowanego procesu analizy i oceny ryzyka. Powoduje to często dość znaczne rozbieżności w dokumentacji tych zakładów oraz utrudnia proces ich weryfikacji i oceny.

Do modelowania skutków uwolnień substancji niebezpiecznych do otoczenia autorzy dokumentacji posługiwali się przede wszystkim następującymi narzędziami informatycznymi:

- PHAST (DNV GL Group - Dania),

- RIZEX-2 (Rizikon - Ukraina),

- ALOHA (CAMEO - USA),

- EFFECTS (TNO - Holandia).
It should be emphasised here that no recommendations have been developed at the central level yet for the following.

- the methodology of assessing the risk of major industrial accidents,

- the types of major accidents which should be considered in the risk analysis process,

- the software used to model the impact of hazardous substance release to the environment,

- the software or computation (estimation) methodology of probability values for accidents.

This means that the authors of documents prepared for each establishment select analysis and risk assessment methods on a case-by-case basis. This often leads to considerable discrepancies in documentation between establishments and complicates the process of their verification and assessment.

The majority of documentation authors used the following software tools for modelling the effects of a potential hazardous substance release to the environment:

- PHAST (DNV GL Group - Denmark),

- RIZEX-2 (Rizikon - Ukraine),

- ALOHA (CAMEO - USA),

- EFFECTS (TNO - The Netherlands). 


\section{Reprezentatywne scenariusze awaryjne w zakładach o dużym ryzyku na Mazowszu}

Analizę reprezentatywnych scenariuszy awaryjnych przeprowadza się w następującym zakresie [19]:

- rodzaj oddziaływania,

- stosowane jednostki charakteryzujące wielkość odziaływania,

- obszary oddziaływania,

- końcowe wartości ryzyka (kategorie),

- możliwość wystąpienia efektu domina.

W 18 zakładach o dużym ryzyku wystąpienia poważnej awarii przemysłowej, zlokalizowanych na terenie województwa mazowieckiego, na potrzeby przeprowadzonej w 2017 roku analizy zagrożeń, wytypowano łącznie 284 reprezentatywne zdarzenia awaryjne, które następnie zostały rozwinięte w konkretne scenariusze awaryjne.

W tabeli 5 przedstawiono liczbę poszczególnych RSA przyporządkowanych do określonego rodzaju czynnika oddziałującego (stwarzającego zagrożenie).

\section{Representative hazard scenarios in upper- tier establishments in the Mazowieckie Voivodeship}

An analysis of representative accident scenarios covers the following aspects [19]:

- impact type,

- respective units characterising the magnitude of impact,

- impact areas,

- final risk values (categories),

- probability of domino effect occurrence.

A total of 284 representative accidents were selected for the purposes of the risk analysis conducted in 2017 in 18 upper-tier establishments located in the Mazowieckie Voivodeship. These representative accidents were then developed into specific accident scenarios.

Table 5 presented the number of each RAS assigned to a specific type of impact (hazard) factor.

Tabela 5. Zestawienie liczby reprezentatywnych scenariuszy awaryjnych w zależności od stwarzanego rodzaju zagrożenia

Table 5. A summary of the number of representative accident scenarios depending on the type of hazard

\begin{tabular}{ccc}
\hline Lp./No. & Czynnik oddziałujący/Impact factor & Liczba RSA/RES number \\
\hline 1 & Promieniowanie cieplne / thermal radiation & 207 \\
\hline 2 & Nadciśnienie / overpressure & 149 \\
\hline 3 & Efekt toksyczny / toxic effect & 81 \\
\hline
\end{tabular}

Źródło: Opracowanie własne na podstawie [19]

Source: Own elaboration based on [19].

Dla 130 scenariuszy wskazano, iż mogą wystąpić zarówno skutki oddziaływania promieniowania cieplnego, jak i nadciśnienia (wybuch i pożar instalacji), natomiast dla 19 scenariuszy określono, iż w wyniku awarii może dojść zarówno do pożaru, wybuchu, jak i utworzenia chmury toksycznej. Na potrzeby zobrazowania poszczególnych rodzajów zagrożeń w przedstawionych raportach o bezpieczeństwie posługiwano się następującymi jednostkami:
130 scenarios were found to potentially involve both thermal radiation and overpressure effects (an explosion and fire within the plant), and 19 scenarios were found to involve potential fire, explosion and toxic vapour cloud events. The following units were used for the purposes of visualising the individual types of hazards presented in the safety reports:

Tabela 6. Jednostki zastosowane w raportach o bezpieczeństwie

Table 6. Units used in the Safety Reports

\begin{tabular}{|c|c|c|c|}
\hline Jednostka/Unit & $\mathrm{kW} / \mathrm{m}^{2}$ & $\mathrm{kPa}$ & - \\
\hline & 1,6 & 3,5 & ERPG1 \\
\hline & 4 & 5 & EGRP2 \\
\hline & 5 & 7 & ERPG3 \\
\hline & 9,5 & 8 & NDSCh \\
\hline & 10 & 10 & NDS \\
\hline Wykorzystywane wartości/ & 12 & 14 & TCLO \\
\hline \multirow[t]{6}{*}{ Used values } & 12,5 & 35 & LCO \\
\hline & 25 & 42 & IDLH \\
\hline & 37,5 & 45 & - \\
\hline & - & 50 & - \\
\hline & _- & 100 & _- \\
\hline & - & 200 & - \\
\hline
\end{tabular}

Źródło: Opracowanie własne na podstawie [19]

Source: Own elaboration based on [19]. 
Przedstawione w analizie RSA ukierunkowano na rodzaje obszarów narażonych. W tej kwestii najbardziej istotnym zagadnieniem jest ocena oddziaływania awarii poza terenem zakładu. Rozpatrując wszystkie RSA, stwierdzono, iż oddziaływanie 215 RSA mieści się w granicach terenu, do którego tytuł prawny posiada prowadzący zakład, zaś dla 79 RSA stwierdzono możliwość oddziaływania na tereny sąsiadujące z terenem zakładu.
The RAS presented in the analysis focused on the types of endangered areas. In this respect the most important issue is to assess the impact of the accident outside the area of the establishment. The analysis of all RAS showed that the impact of 215 RAS is within the area of the establishment for which the manager has a legal title and 79 RAS were found to exert potential impact on the areas adjoining the area of the establishment.

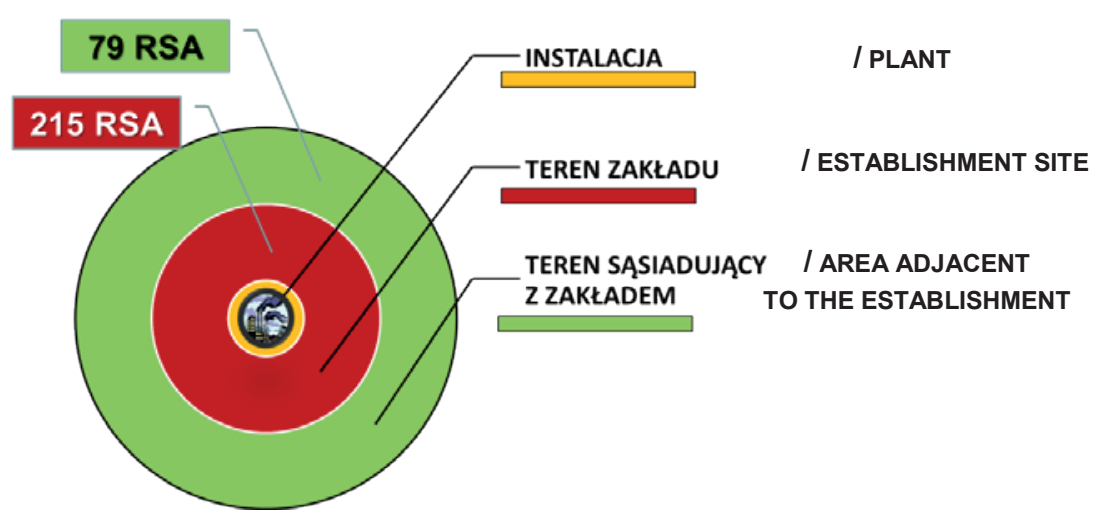

Rycina 6. Podział reprezentatywnych scenariuszy awaryjnych (RSA) w zależności od obszaru narażenia

Figure. 6. Division of representative accident scenarios (RAS) according to the exposure area.

Źródło: Opracowanie własne na podstawie [19].

Source: Own elaboration based on [19].

W ramach przeprowadzonego w 2017 roku badania dokonano również szczegółowej analizy wielkości i rodzajów obszarów znajdujących się poza terenem zakładu i jednocześnie objętych zasięgiem oddziaływania zagrożeń. Dane o tych obszarach zaczerpnięto z reprezentatywnych scenariuszy awaryjnych opisanych w raportach o bezpieczeństwie. Ustalono, iż wielkość obszaru wynosi ok. 2300 ha, co stanowi w przybliżeniu kwadrat o boku długości ok. 4,8 km (odpowiednik powierzchni ok. 3220 standardowych boisk piłkarskich). Rodzaje terenów narażonych na oddziaływania poza terenem zakładu to: obszary leśne, pola uprawne, pojedyncza zabudowa mieszkaniowa, inne instalacje procesowe (obszar PKN ORLEN w Płocku, w obrębie którego poszczególne instalacje mogą na siebie oddziaływać w przypadku awarii) oraz obiekty magazynowe. Dla trzech zakładów stwierdzono oddziaływania na zwartą zabudowę mieszkaniową i biurową, jednakże dotyczy to zdarzeń, których oszacowane prawdopodobieństwo wystąpienia zawiera się na poziomie raz na milion lat.

W wyniku przeprowadzonych w roku 2017 analiz zagrożeń, przy zastosowaniu indywidualnej dla danego zakładu matrycy ryzyka, wynikowe wartości (kategorie) ryzyka wystąpienia danego zdarzenia kształtowały się następująco (zob. tabela 7).
The study conducted in 2017 included a detailed analysis of the sizes and types of areas located outside the area of the establishment and at the same time covered by the impact range of the threats. Information about these areas were extracted form representative accident scenarios described in the safety reports. It was found that this area was approx. 2,300 ha, which is roughly a square with the side of approx. $4.8 \mathrm{~km}$ (equivalent to the area of 3,220 standard football pitches). Types of areas endangered by impacts outside the area of the establishment are forest areas, arable land, single-family housing, other process plants (the area of PKN ORLEN in Płock within which the individual plants may affect each other in the event of an accident) and warehouses. Three establishments were found to affect high-density residential and office development, although this relates to events with the estimated probability of occurrence of once in 1 million years.

The hazard analyses conducted in 2017 using the risk matrices specific to each establishment yielded the following values (categories) of risk of occurrence for specific accidents (see Table 7). 
Tabela 7. Zestawienie wartości (kategorii) ryzyka dla RSA

Table 7. Summary of risk categories for RES

\begin{tabular}{|cc|}
\hline Kategoria ryzyka/Risk category & Liczba RSA/RES number \\
\hline 1 & 2 \\
\hline A & 86 \\
\hline TA & 195 \\
\hline TNA & 3 \\
\hline NA & 0 \\
\hline Razem / Total & 284 \\
\hline
\end{tabular}

Poszczególne wynikowe kategorie ryzyka oznaczają [14]/The individual resulting risk categories are identified as [14]:

A - ryzyko akceptowane - nie wymagane są żadne dodatkowe środki bezpieczeństwa/acceptable risk - no extraordinary measures are required, TA - ryzyko tolerowane akceptowane - stosowanie zasady ALARP (utrzymywanie ryzyka na poziomie tak niskim, jak to praktycznie możliwe, dokonać oceny alternatyw) / tolerable and acceptable risk - apply ALARP principle (risk shall be reduced as far as reasonably practicable, evaluate alternatives)

TNA - ryzyko tolerowane nieakceptowane - wprowadzić dodatkowe środki bezpieczeństwa w terminie 3-6 miesięcy/tolerable and unacceptable risk - extraordinary measures are required within 3-6 months,

NA - ryzyko nieakceptowane - zatrzymać instalację/unacceptable risk - stop the operation of the plant.

Źródło: Opracowanie własne na podstawie [19]

Source: Own elaboration based on [19].

Ostatnim parametrem reprezentatywnych scenariuszy awaryjnych, który wzięto pod uwagę, jest możliwość (potencjał) spowodowania wystąpienia efektu domino.

Pod pojęciem efekt domino należy rozumieć takie zdarzenie, w wyniku którego następuje uwolnienie substancji niebezpiecznych w określonej instalacji procesowej wtórnej wskutek oddziaływania efektów fizycznych związanych z uwolnieniem substancji niebezpiecznych w instalacji pierwotnej, znajdującej się w sąsiedztwie instalacji wtórnej [14].

Przeprowadzona w roku 2017 analiza zagrożeń wykazała, iż w wyniku wystąpienia 217 RSA może wystąpić efekt domino. Powyższe dotyczy 14 z 18 zakładów zlokalizowanych na terenie Mazowsza.

\section{Bezpieczne odległości w planowaniu przestrzennym}

Zgodnie z art. 13 obecnie obowiązującej Dyrektywy Seveso III [5] państwa członkowskie są zobligowane, aby w procesie planowania i zagospodarowania przestrzennego lub w ramach innych odpowiednich obszarów kształtowania lokalizacji zakładów i planowania przestrzennego uwzględniać cele odnoszące się do zapobiegania poważnym awariom przemysłowym jak również ograniczania ich skutków dla zdrowia ludzkiego i środowiska.

Dalej w art. 13 Dyrektywy Seveso III czytamy, że poszczególne państwa Unii Europejskiej mają spełniać powyższy obowiązek poprzez kontrolę:

- lokalizacji nowych zakładów;

- zmian w zakładach objętych art. 11 przedmiotowej Dyrektywy - czyli zmian w zakładach istniejących;
The last parameter of the representative accident scenarios taken into consideration is the probability (potential) of causing the domino effect.

The domino effect should be understood as an event which results in the release of hazardous substances in a specific secondary process plant as a result of the physical effects connected with the release of hazardous substances in the primary plant located in the vicinity of the secondary plant [14].

The hazard analysis conducted in 2017 demonstrated that the domino effect may occur for 217 RAS. The above figure includes 14 out of 18 establishments located in the Mazowieckie Voivodeship.

\section{Safety distances in spatial planning}

Pursuant to Article 13 of the currently applicable Seveso III Directive [5], Member States shall ensure that the objectives of preventing major accidents and limiting the consequences of such accidents for human health and the environment are taken into account in their land use policies or other relevant policies determining the siting of new establishments and land use.

Article 13 of the Seveso III Directive further stipulates that individual Member States of the European Union shall take into account the issue of major industrial accidents through controls on:

- the siting of new establishments;

- modifications to establishments covered by Article 11 of the Directive, i.e. changes to existing establishments; 
- nowych obiektów budowlanych, inwestycji, takich jak połączenia transportowe, miejsca użyteczności publicznej i tereny zabudowy mieszkalnej usytuowane w pobliżu zakładów, gdzie lokalizacja lub inwestycje mogą być źródłem poważnej awarii lub mogą zwiększyć ryzyko poważnej awarii lub skutki takiej awarii $[5,11]$.

Zapisy określające zakres kontroli zostały transponowane w praktycznie niezmienionej formie do ustawy z dnia 27 marca 2003 r. o planowaniu i zagospodarowaniu przestrzennym, będącym aktem prawnym normującym kwestie planowania i zagospodarowania przestrzennego w Polsce [1]. Jako instytucje właściwe do zajmowania stanowiska w przedmiotowym zakresie podczas uchwalania studiów uwarunkowań i kierunków zagospodarowania przestrzennego, miejscowych planów zagospodarowania przestrzennego czy wydawania decyzji o warunkach zabudowy wskazano organy Państwowej Straży Pożarnej i Wojewódzki Inspektorat Ochrony Środowiska.

W dalszej kolejności w art. 13 Dyrektywy Seveso III wskazano, iż w procesie planistycznym lub innym właściwym obszarze należy w sposób długoterminowy uwzględnić lokalizację zakładów "sevesowskich" poprzez:

a) utrzymanie bezpiecznych odległości między zakładami objętymi Dyrektywą Seveso a obszarami zabudowy mieszkalnej, budynkami i obszarami przestrzeni publicznej, obszarami wypoczynkowymi oraz, o ile to możliwe, głównymi szlakami służącymi do komunikacji;

b) ochronę obszarów wrażliwych ze względu na formy ochrony przyrody lub obszary szczególnego zainteresowania zlokalizowane w pobliżu zakładów, poprzez zachowanie bezpiecznych odległości lub zastosowanie odpowiednich środków;

c) w przypadku istniejących zakładów wprowadzenia dodatkowych środków technicznych, tak aby nie zwiększać ryzyka dla zdrowia ludzkiego i środowiska.

W dalszej kolejności zapisy Dyrektywy Seveso III nakładają na kraje UE obowiązek ustalenia odpowiednich procedur konsultacyjnych przez właściwe organy, w tym te do spraw planowania i zagospodarowania przestrzennego ułatwiających realizację wyznaczonych w art. 13 kierunków polityki planistycznej w kontekście funkcjonowania zakładów objętych zakresem dyrektywy $[10,12]$.

Zapisy Dyrektywy jednoznacznie wskazują, iż informacji wykorzystywanych na potrzeby planistyczne dotyczące ryzyka związanego z uruchomieniem zakładu o zwiększonym lub dużym ryzyku wystąpienia poważnej awarii przemysłowej dostarcza prowadzący zakład. Zapis wskazujący stronę zobowiązaną do opracowania i przedłożenia niezbędnych informacji pozwala dobierać odpowiednie procedury konsultacyjne pod najistotniejszym kątem, mianowicie podmiotu zobowiązanego do opracowania i dostarczenia informacji niezbędnych do planowania i zagospodarowania przestrzennego. Reasumując powyższe, prowadzący zakład zgodnie z zapisami Dyrektywy Seveso III jest zobowiązany dostarczyć właściwemu organowi realizującemu politykę planistyczną oraz właściwemu organowi architektonicznemu niezbędne informacje o zagrożeniach stwarzanych przez zakład.
- new developments, including transport routes, locations of public use and residential areas in the vicinity of establishments, where the siting or developments may be the source of or increase the risk or consequences of a major accident $[5,11]$.

The provisions specifying the scope of control were transposed in a virtually unchanged wording to the Act of 27 March 2013 on Land Use and Spatial Planning, which is the normative legal regulation for land use and spatial planning in Poland [1]. The State Fire Service and the Voivodeship Inspectorate of Environmental Protection were designated as the competent authorities to opine on the said scope when passing development strategy documents, local development plans and issuing zoning approvals.

Article 13 of the Seveso III Directive further indicates that in the planning process or in other relevant areas, the siting of Seveso establishments should be taken into account in the long term by:

a) maintaining appropriate safety distances between establishments covered by the Seveso Directive and residential areas, buildings and public areas, recreational areas, and, as far as possible, major transport routes;

b) protecting areas of particular natural sensitivity or interest in the vicinity of establishments through appropriate safety distances or other relevant measures;

c) in the case of existing establishments, taking additional technical measures so as not to increase the risks to human health and the environment.

The Seveso III Directive also require EU Member States to ensure that all competent authorities and planning authorities establish appropriate consultation procedures to facilitate the implementation of the planning policies set by Article 13 in the context of the operation of establishments covered by the Directives $[10,12]$.

The provisions of the Directive clearly indicate that the information necessary for planning purposes related to the risk connected with opening a new lower-tier or upper-tier establishment is submitted by the operator. The provision indicating the party obliged to prepare and submit the relevant information makes it possible to select appropriate consultation procedures according to the most important perspective, i.e. that of the entity obliged to prepare and provide information necessary for land use and spatial planning.

To summarise, pursuant to the Seveso III Directive, the operator of an establishment is obliged to provide the necessary information about the hazards caused by the establishment to the competent authority implementing the planning policy and the competent construction authority.

The State Fire Service and the Voivodeship Inspectorates of Environmental Protection have the duty to supervise how safety distances and other site constraints are taken into account. As an analysis of existing legislation indicates, it is extremely difficult to ensure that issues connected with major accidents are taken into account in the spatial planning process. Local governments and construction authorities are responsible for taking these issues into consideration. Supervision and 
Organy PSP oraz WIOŚ mają za zadanie nadzorować sposób uwzględniania kwestii bezpiecznych odległości i innych ograniczeń lokalizacyjnych. Niezmiernie trudne, jak można wywnioskować z obecnie obowiązującego stanu prawnego, jest zapewnienie uwzględniania zagadnień związanych z poważnymi awariami w procesie planowania przestrzennego. Za uwzględnianie tej problematyki odpowiedzialne są samorządy oraz organy architektoniczno-budowlane. Organy PSP i WIOŚ otrzymały funkcję kontrolno-ocenną.

Prawo Unii Europejskiej nałożyło na kraje członkowskie obowiązek brania pod uwagę zagrożeń stwarzanych przez zakłady zwiększonego i dużego ryzyka w procesie planistycznym oraz obowiązek uwzględniania oddziaływania otoczenia na zakład. Nakazano również kontrolować kwestię zarządzania zmianami w istniejących zakładach. Na prowadzącego zakład może zostać nałożony obowiązek zastosowania dodatkowych zabezpieczeń technicznych w celu minimalizacji niebezpieczeństw, na jakie narażeni są ludzie.

W procesie planowania przestrzennego aktami podlegającymi analizie i ocenie są: studium uwarunkowań i kierunków zagospodarowania przestrzennego, projekt miejscowego planu zagospodarowania przestrzennego oraz projekt decyzji o warunkach zabudowy. W procesie konsultacji społecznych i administracyjnych ww. operatów i decyzji powinno uwzględniać się całokształt relacji przestrzennych, wynikających z ryzyka wystąpienia poważnych awarii przemysłowych.

Zgodnie z brzmieniem ustawy o planowaniu i zagospodarowaniu przestrzennym właściwe organy PSP i WIOŚ opiniują projekty studiów oraz projekty miejscowych planów zagospodarowania przestrzennego w zakresie:

- lokalizacji nowych zakładów o zwiększonym lub dużym ryzyku wystąpienia poważnych awarii,

- istotnych zmian, o których mowa w ustawie z Prawo ochrony środowiska, w istniejących zakładach o zwiększonym lub dużym ryzyku wystąpienia poważnych awarii,

- nowych inwestycji oraz rozmieszczenia obszarów przestrzeni publicznej i terenów zabudowy mieszkaniowej w sąsiedztwie zakładów o zwiększonym lub dużym ryzyku wystąpienia poważnych awarii, w przypadku, gdy ich lokalizacja zwiększa ryzyko lub skutki poważnych awarii [1].

Ustawodawca przewidział również tryb wyjątkowy możliwy do wykorzystania w przypadku braku miejscowego planu zagospodarowania przestrzennego - mianowicie kształtowanie przeznaczenia terenów poprzez decyzje o warunkach zabudowy (potocznie "wuzetki") [1]. W koncepcji rozwiązanie to miało mieć charakter wyjątkowy, stało się jednak furtką umożliwiającą przeznaczanie terenów pod określoną zabudowę z pominięciem bardziej sformalizowanych procedur przewidzianych dla miejscowych planów zagospodarowania przestrzennego - bardziej czasochłonnych i droższych. Obowiązek uzgadniania przez organy PSP i WIOŚ decyzji o warunkach zabudowy oraz decyzji o lokalizacji inwestycji celu publicznego wynika $z$ art. 53 ust. 4 pkt 12 oraz art. 64 ust. 1 ustawy o planowaniu i zagospodarowaniu przestrzennym. Wskazać w tym miejscu należy, iż organami właściwymi do wydawania "wuzetek" są wójt, burmistrz i prezydent miasta. W obecnym stanie prawnym to te organy decydują, dla których obszarów należy podjąć proces assessment, in turn, is within the remit of the State Fire Service and the Voivodeship Inspectorates of Environmental Protection.

EU law requires Member States to take into account in their planning processes the risks created by lower- and upper-tier establishments and the assessment of the impact of the surrounding area on the establishment. They are also required to supervise the management of modifications in existing establishments. An operator may be obligated to apply additional technical measures to minimise the risks to human health and life.

In the spatial planning process, the documents subject to analysis and assessment are development strategy documents, draft local development plans and draft zoning approvals. The process of public and administrative consultations on surveys and decisions should take into account the entirety of spatial relations related to the risk of occurrence of major industrial accidents.

Pursuant to the Act on Spatial Planning and Management, the relevant units of the State Fire Service and Voivodeship Inspectorates of Environmental Protection provide their opinions on draft development strategy documents and draft local development plans with regard to:

- siting new lower- or upper-tier establishments,

- significant modifications, as mentioned in the Environmental Protection Law, to existing lower- or upper-tier establishments,

- new developments and the siting of public areas and residential areas in the vicinity of lower- or upper-tier establishments, where the siting or developments may increase the risk or consequences of a major accident [1].

The legislator also provided for a special procedure which may be followed where no local development plan is in place, which involves defining land use by means of zoning approvals (often referred to as "ZA"). This solution was meant to be used for special cases, but it became a loophole allowing the approval of certain areas for specific developments while avoiding more formalised procedures such as those defined for local development plans, which are more time-consuming and cost-intensive. The obligation for the State Fire Service and Voivodeship Inspectorates of Environmental Protection to consult on zoning approvals and decisions regarding the location of public-purpose projects is provided for in Article 53 (4) (12) and Article 64 (1) of the Act on Land Use and Spatial Planning. It should be noted here that the authorities competent to issue "ZAs" are commune heads and city mayors. Under existing legislation, it is these authorities that decide in which areas the consultation process for "ZAs" with the State Fire Service and the Voivodeship Inspectorates of Environmental Protection should be initiated, and in which it is not necessary. This is due to the fact that information on the range of impact of major industrial accidents is not widely published - this data is in the possession of the State Fire Service and Voivodeship Inspectorates of Environmental Protection.

All important information needed for the purposes of spatial planning must be included in the documentation required for upper-tier establishments. This data includes, in particular, 
uzgadniania projektu „wuzetki” z organami PSP i WIOŚ, a dla których można go pominąć. Dzieje się tak, ponieważ w chwili obecnej informacje o zasięgach oddziaływania poważnych awarii przemysłowych nie podlegają szerokiej publikacji - są to dane będące w posiadaniu organów PSP i WIOŚ.

Wszystkie informacje przydatne w planowaniu przestrzennym znajdują się $w$ dokumentacji przewidzianej dla zakładu o dużym ryzyku. Do tych danych w szczególności można zaliczyć opis zidentyfikowanych zagrożeń i przeprowadzonej analizy ryzyka wystąpienia poważnej awarii. Raport o bezpieczeństwie spełniający wymogi rozporządzenia ministra Rozwoju [8] zawiera zasięgi i skutki zidentyfikowanych poważnych awarii przemysłowych z uwzględnieniem terenów zamieszkałych, gęstości zaludnienia i rodzaju zabudowy, form ochrony przyrody, w tym dokumentację graficzną. Dodatkowo, w raporcie o bezpieczeństwie powinny znaleźć się informacje istotne dla celów planowania i zagospodarowania przestrzennego. Organy PSP i WIOŚ w posiadanym raporcie o bezpieczeństwie dysponują informacjami przydatnymi w procesie planowania przestrzennego w otoczeniu istniejących zakładów dużego ryzyka [8].

Biorąc pod uwagę doktrynę zapobiegania poważnym awariom przemysłowym [5] oraz dostępne informacje o rodzaju możliwych do wystąpienia zdarzeń awaryjnych, prawdopodobieństwie ich wystąpienia, zasięgu oddziaływania oraz prognozowanych skutkach, można określić dość jednoznacznie definicję bezpiecznej odległości - jest to odległość (dystans), która ma za zadanie złagodzić negatywne skutki poważnych awarii przemysłowych i zapobiec ich eskalacji lub powstaniu efektu domino. Odległość, rozumiana jako dystans między dwoma osobnymi obiektami w przestrzeni, jest najpewniejszą, a często również najtańszą metodą ograniczania skutków awarii w przypadku jej wystąpienia. Obecnie podejmowana jest próba sporządzenia aktu prawnego [22], w którym przedstawione zostaną ścieżka postępowania w przedmiocie ustalania bezpiecznej odległości oraz kryteria progowe oddziaływania poważnych awarii w zakresie promieniowania cieplnego, nadciśnienia i toksyczności W dokumencie określona zostanie graniczna wartość prawdopodobieństwa wystąpienia takich zdarzeń, warunkująca potrzebę uwzględnienia ich w procesie planowania i zagospodarowania przestrzennego.

\section{Podsumowanie i wnioski}

Na podstawie przeanalizowanych raportów o bezpieczeństwie oraz przeglądu aktów prawnych i dostępnych wytycznych można sformułować następujące wnioski:

1. Ilość danych w raportach o bezpieczeństwie zakładów o dużym ryzyku w zakresie analizy i oceny ryzyka wystąpienia poważnych awarii przemysłowych jest bardzo duża; dokumenty te charakteryzują się wysokim stopniem skomplikowania; w związku z tym istnieje potrzeba wprowadzenia systemu zarządzania, który pozwoli wykorzystać te dane w realizowanych procesach analizy i oceny projektów miejscowych planów zagospodarowania przestrzennego i projektów decyzji o warunkach zabudowy. a description of the identified hazards and an analysis of the risk of major industrial accidents. A safety report fulfilling the requirements of the Regulation of the Minister of Development [8] lists the ranges and impacts of identified major industrial accidents, taking into account inhabited areas, population density, type of development, and forms of environmental protection, including visual documentation. Additionally, the safety report should contain information on the data provided for the purposes of land use and spatial planning. Safety reports provide the State Fire Service and Voivodeship Inspectorates of Environmental Protection with information useful in the spatial planning involving areas surrounding existing upper-tier establishments [8].

Taking into account the doctrine of preventing major industrial accidents [5] and the available information on the types of potential accidents, their probability, range of impact and projected consequences, a relatively clear definition of safety distance can be provided - it is the distance necessary to mitigate the adverse consequences of major industrial accidents and prevent their escalation or the domino effect. The distance, understood as the amount of space between two objects, is the most reliable and often the cheapest method of reducing the impact of accidents. Currently, attempts are being made to draft legislation [22] that will guide the determination of safety distance and indicate the threshold impact criteria for major industrial accidents in terms of thermal radiation, overpressure and toxicity, providing a cut-off value for the probability of such events that should be used for the purposes of land use and spatial planning.

\section{Summary and conclusions}

The following conclusions were drawn from the analysis of safety reports and review of existing legislation and available guidelines.

1. The data presented in the safety reports of upper-tier establishments with regard to the analysis and assessment of the risk of major industrial accidents is very extensive and highly complicated; therefore, there is a need for a management system that would ensure their use in the analysis and assessment of draft local development plans and draft zoning approvals.

2. There is no specific, centrally recommended risk assessment methodology, which is why individual risk 
2. Brak określonej, zarekomendowanej na szczeblu centralnym metodyki dokonywania oceny ryzyka prowadzi do tego, że poszczególne oceny w raportach o bezpieczeństwie oparte są na odmiennych zasadach; w przypadku podobnych zakładów powoduje to powstawanie rozbieżności w zakresie rozpatrywanych reprezentatywnych zdarzeń awaryjnych, obliczania wartości prawdopodobieństwa i szacowania ryzyka.

3. Brak standaryzacji wymagań w zakresie prezentacji wyników analiz i ocen ryzyka, a w szczególności zasięgów oddziaływania promieniowania cieplnego, nadciśnienia i toksyczności powoduje pełną dowolność, uniemożliwiającą jednoznaczną interpretację tych wyników. Bez wykorzystania określonego oprogramowania nie ma również możliwości dokonywania dokładnych interpolacji danych. Oceniający otrzymuje zestawy różnych wartości progowych w różnych wielkościach fizycznych, co skutkuje stosowaniem zasady ograniczonego zaufania - pod uwagę brane są minimalne wartości oddziaływania, które zgodnie z dostępną wiedzą techniczną nie powinny odgrywać wiążącej roli w procesie opiniowania projektów miejscowych planów zagospodarowania przestrzennego i uzgadniania projektów decyzji o warunkach zabudowy.

4. Potencjał oddziaływania reprezentatywnych scenariuszy awaryjnych jest bardzo duży. Dotyczy to zarówno terenu zakładu, jak i obszaru sąsiadującego z zakładem. Wyniki dokonanej w 2017 roku dla województwa mazowieckiego analizy zagrożeń wykazały, iż obszar objęty oddziaływaniem zakładów o dużym ryzyku wystąpienia poważnej awarii poza swoim terenem jest równy ok. 2300 ha.

5. Brak krajowych wytycznych w zakresie ustalania bezpiecznej odległości na potrzeby planowania i zagospodarowania przestrzennego powoduje, że ww. obszar podlega określonym rodzajom zagospodarowania (zabudowy) z pominięciem lub niedostatecznym uwzględnieniem informacji o oddziaływaniu poważnych awarii przemysłowych.

Podsumowując dane z wykonanej w Komendzie Wojewódzkiej PSP w Warszawie w 2017 roku analizy reprezentatywnych scenariuszy awaryjnych zakładów o dużym ryzyku wystąpienia poważnej awarii przemysłowej na przykładzie województwa mazowieckiego, stwierdzić należy, iż obowiązujący stan prawny na styku zapobiegania poważnym awariom przemysłowym a planowaniem i zagospodarowaniem przestrzennym jest wysoce niezadowalający., Skutkuje to brakiem ograniczeń co do rodzaju i formy zagospodarowania (zabudowy) terenu, będącego w zasięgu oddziaływania poważnej awarii przemysłowej lub, w drugą stronę, wprowadzaniem ograniczeń w sposób niewspółmierny do rodzaju i wartości oddziaływania możliwych do przewidzenia skutków. Przedstawiona łączna wielkość oddziaływania skutków analizowanych awarii poza terenami zakładów $\left(23 \mathrm{~km}^{2}\right)$, stanowiąca równowartość powierzchni takich miast w Polsce jak Łowicz, Pułtusk, Radzymin czy Dąbrowa Białostocka [23], jednoznacznie wskazuje na pilną potrzebę stworzenia odpowiednich regulacji prawnych, a następnie ich wdrożenia i nadzorowania w celu osiągnięcia założonego celu. Zdaniem autorów, stworzenie krajowych wytycznych powinno być poprzedzone szczegółowymi analizami obecnego systemu planowania i zagospodarowania przestrzen- assessments in safety reports follow different rules and principles, leading to differences with regard to the analysed representative accidents, probability calculations and risk assessments across similar establishments.

3. The lack of standardisation of requirements for presenting the results of analyses and risk assessments, particularly with regard to the range of impact of thermal radiation, overpressure and toxicity, leads to complete arbitrariness that prevents the clear interpretation of these results. Without using specific software, it is also impossible to perform accurate data interpolation. The person conducting a review receives sets of different threshold values in a variety of physical units which leads to a sceptical approach - minimum impact values are considered, as, according to the currently available technical knowledge, they should not play a binding role in the process of assessing draft local development plans and negotiating draft zoning approvals.

4. The impact potential of representative accident scenarios is very high. This concerns both the area of the establishment and its adjoining area. The results of the hazard analysis conducted in 2017 for the Mazowieckie Voivodeship demonstrated that the area covered by the impact of upper-tier establishments outside their area is approx. 2,300 ha.

5. Due to the lack of national guidelines for determining safety distances for the purposes of spatial planning and land use, this area is covered by specific types of land development (buildings), while disregarding or insufficiently highlighting information on the potential impact of major industrial accidents.

To summarise the data obtained in the analysis of representative accident scenarios for upper-tier establishments conducted in 2017 by the Mazovian Headquarters of the State Fire Service in Warsaw, drawing on the example of the Mazowieckie Voivodeship, it should be concluded that under existing legislation with regard to the prevention of major industrial accidents and land use and spatial planning highly unsatisfactory. As a result, no restrictions have been imposed on the type and form of land use (buildings) within the area of impact of potential major industrial accidents, or, conversely, excessive restrictions have been put into place for the type and extent of impact of potential foreseeable accidents. The presented total area of impact of the analysed accidents outside the areas of the establishments $\left(23 \mathrm{~km}^{2}\right)$, which is equivalent to the areas of such Polish towns as Łowicz, Puttusk, Radzymin or Dąbrowa Białostocka [23], clearly suggests that in order to achieve the set objective, there is an urgent need to draft, enact and monitor appropriate legislation. According to the authors, developing national guidelines should be preceded by a number of detailed analyses of the current land use and spatial planning system, the threshold values applied to impacts of potential major accidents and also the planned permits for specific spatial development types in the areas covered by the impact range of potential major industrial accidents. The range of impact of the planned legal regulations 
nego, stosowanych wartości progowych oddziaływań poważnych awarii, a także planowanych dopuszczeń rodzajów zagospodarowania terenu na terenach objętych odziaływaniem poważnych awarii przemysłowych. Zasięg oddziaływania planowanych regulacji prawnych na procesy prawne dotyczące kształtowania ładu przestrzennego, budowlanych procesów inwestycyjnych i zapobiegania poważnym awariom przemysłowym wymusza konieczność uprzedniego, wnikliwego zbadania i rozstrzygnięcia kwestii spornych. W innym wypadku nastąpi dalsze rozregulowanie przedmiotowego obszaru, co odbije się negatywnie na systemie zapobiegania poważnym awariom przemysłowym w Polsce.

Publikacja została opracowana w ramach projektu nr DOB-BI07/09/03/2015 finansowanego przez Narodowe Centrum Badań i Rozwoju pod tytułem „Program do oceny ryzyka w obiektach przemysłowych, stwarzających zagrożenie poza swoim terenem".

\section{Literatura/Literature}

[1] Ustawa z dnia 27 marca 2003 r. o planowaniu i zagospodarowaniu przestrzennym (t.j. Dz. U. z 2018 r. poz. 1945).

[2] Ustawa z dnia 27 kwietnia 2001 r. Prawo ochrony środowiska (t.j. Dz. U. z 2018 r. poz. 799 ze zm.).

[3] Dyrektywa 82/501/EWG z dnia 24 czerwca 1982 roku w sprawie niebezpieczeństwa poważnych awarii, powodowanych przez określone działania przemysłowe.

[4] Dyrektywa Rady 96/82/WE z 9 grudnia 1996 r. w sprawie kontroli niebezpieczeństwa poważnych awarii związanych z substancjami niebezpiecznymi.

[5] Dyrektywa Parlamentu Europejskiego i Rady 2012/18/UE z 4 lipca 2012 r. w sprawie kontroli zagrożeń poważnymi awariami związanymi z substancjami niebezpiecznymi.

[6] Globally Harmonized System of Classification and Labelling of Chemicals (GHS), United Nations Bookshop GA-1B-103, New York, USA.

[7] Rozporządzenie Parlamentu Europejskiego i Rady (WE) nr 1272/2008 z dnia 16 grudnia 2008 r. w sprawie klasyfikacji, oznakowania i pakowania substancji i mieszanin, zmieniające i uchylające Dyrektywy 67/548/EWG] i 1999/45/WE oraz zmieniające rozporządzenie (WE) nr 1907/2006 (Dz. Urz. UE L 353 z 31.12.2008).

[8] Rozporządzenie Ministra Rozwoju z dnia 23 lutego 2016 r. w sprawie raportu o bezpieczeństwie zakładu o dużym ryzyku (Dz. U. z 2016 r. poz. 287).

[9] Rocznik Statystyczny Województwa Mazowieckiego, GUS, Warszawa 2016.

[10] Christou M. D., Amendola A., Smeder M., The control of major accident hazards: The land-use planning issue, "Journal of Hazardous Materials", 1999, 65(1-2), , 151-178.

[11] Cozzani V., Bandini R., Basta C., Christou M.D., Application of landuse planning criteria for the control of major accident hazards: A casestudy, "Journal of Hazardous Materials", 2006, A136, , 170-180.

[12] Christou M., Gyenes Z., Struckle M., Risk assessment in support to land use planning in Europe: towards more consistent decisions?, "Journal of Loss Prevention in the Process Industries", 2011, 24.(3), 219-226. on the legal processes relating to spatial governance, construction investment and the prevention of major industrial accidents makes it necessary to perform a detailed analysis of and solve any contentious issues before their implementation. Failing that, a further deregulation will take place, additionally compromising the system of preventing major industrial accidents in Poland.

The publication was prepared within the project No. DOBBI07/09/03/2015 financed by the National Centre for Research and Development under the title "Software for risk assessment in industrial establishments generating hazards beyond their area".

[13] Lees F.P, Loss Prevention in Process Industries, Butterworths, 1980

[14] Markowski A.S. (red.), Zapobieganie stratom w przemyśle. Część III - Zarządzanie bezpieczeństwem procesowym, praca zbiorowa, Politechnika Łódzka, Łódź 2000.

[15] Lesiak P., Porowski R., Ocena skutków awarii przemysłowej w instalacjach procesowych w tym efektu domino - część I, BiTP Vol. 27 Issue 3, 2012, pp. 13-25.

[16] Metodologia ustalania bezpiecznych lokalizacji zakładów mogących powodować poważne awarie, GIOŚ, Warszawa 2010.

[17] Wiśniewski W., Roczny plan kontroli w zakresie przestrzegania przepisów dotyczących przeciwdziałania awarii przemysłowej na terenie województwa mazowieckiego, Wydział Kontrolno-Rozpoznawczy Komendy Wojewódzkiej Państwowej Straży Pożarnej w Warszawie, 15 października $2015 \mathrm{r}$.

[18] Wiśniewski W., Analiza Zagrożeń Województwa Mazowieckiego, Wydział Kontrolno-Rozpoznawczy Komendy Wojewódzkiej Państwowej Straży Pożarnej w Warszawie, luty 2017.

[19] Wiśniewski W., Analiza zagrożeń stwarzanych przez zakłady o dużym ryzyku wystąpienia poważnej awarii przemysłowej poza swoim terenem - województwo mazowieckie, Wydział Kontrolno-Rozpoznawczy Komendy Wojewódzkiej Państwowej Straży Pożarnej w Warszawie, czerwiec 2016.

[20] Zagrożenia poważnymi awariami przemysłowymi w Polsce, CIOP, Warszawa 2015, [dok. elektr.] https://www.ciop.pl [dostęp: marzec 2016].

[21] Sobieszek G., Planowanie i zagospodarowanie przestrzenne na t/e problematyki sposobu ustalania bezpiecznej odległości przy lokalizacji zakładów stwarzających zagrożenie wystąpienia poważnej awarii przemysłowej, praca magisterska, SGSP, Warszawa 2016.

[22] Projekt rozporządzenia Ministra Środowiska z dnia 27 marca 2015 r. w sprawie sposobu ustalania bezpiecznej odległości przy lokalizacji zakładów stwarzających zagrożenie wystąpienia poważnej awarii przemysłowej.

[23] Powierzchnia i ludność w przekroju terytorialnym w 2016 r., GUS, Warszawa 2016 
MGR BARTŁOMIEJ POŁEĆ - absolwent Wydziału Bezpieczeństwa Narodowego Akademii Obrony Narodowej w Warszawie (obecnie Akademia Sztuki Wojennej). Pracownik Jednostki Certyfikującej Usługi CNBOP-PIB. Wspóltwórca projektów badawczo-rozwojowych realizowanych przez CNBOP-PIB we współpracy z innymi instytucjami. Pełni funkcję zastępcy kierownika w projekcie naukowo-badawczym pn. „Program do oceny ryzyka w obiektach przemysłowych, stwarzających zagrożenie poza swoim terenem".

ST. KPT. MGR INŻ. WOJCIECH WIŚNIEWSKI - kierownik sekcji w Wydziale Kontrolno-Rozpoznawczym Komendy Wojewódzkiej Państwowej Straży Pożarnej w Warszawie. Absolwent dziennych mundurowych studiów inżynierskich na Wydziale Inżynierii Bezpieczeństwa Pożarowego Szkoły Głównej Służby Pożarniczej oraz studiów podyplomowych „Bezpieczeństwo procesów przemysłowych” na Politechnice Łódzkiej. Brał czynny udział w procesie implementowania dyrektywy SEVESO III do prawodawstwa krajowego. Prowadzi działania kontrolne w zakładach sevesowskich. Jest autorem wielu analiz i wystąpień w dziedzinie bezpieczeństwa procesowego oraz oceny ryzyka. Kieruje projektem naukowo-badawczym pn. „Program do oceny ryzyka w obiektach przemysłowych, stwarzających zagrożenie poza swoim terenem".

Mt. KPT. MGR INŻ. GRZEGORZ SOBIESZEK - absolwent Dziennego Studium Aspirantów PSP w Częstochowie, Wojskowej Akademii Technicznej w Warszawie (kierunek chemia) oraz studiów magisterskich na Wydziale Inżynierii Bezpieczeństwa Pożarowego Szkoły Głównej Służby Pożarniczej. Ukończył także studia podyplomowe dla strażaków ubiegających się o zajmowanie stanowisk oficerskich związanych z kierowaniem działaniami ratowniczymi w Szkole Głównej Służby Pożarniczej. Od 2013 roku pełni służbę w Komendzie Wojewódzkiej Państwowej Straży Pożarnej w Warszawie w Wydziale Kontrolno-Rozpoznawczym na stanowisku specjalisty.
BARTŁOMIEJ POŁEĆ, M.A. - graduated from the Faculty of National Security of the National Defense University in Warsaw (currently War Studies University). Employed at the Services Certification Department of the Scientific and Research Centre for Fire Protection - National Research Institute (CNBOP-PIB). He has co-created a number of research and development projects implemented by CNBOP-PIB in cooperation with other institutions. He is also a deputy manager in a scientific research project entitled "Software for risk assessment in industrial establishments generating hazards beyond their area".

ST. KPT. WOJCIECH WIŚNIEWSKI, M.ENG. - Division Manager at the Inspection and Evaluation Department of the Mazovian Headquarters of the State Fire Service in Warsaw. He graduated from full-time engineering studies for uniformed services at the Fire Safety Engineering Faculty of the Main School of Fire Service and completed postgraduate studies in "Industrial process safety" at the Lodz University of Technology. He actively participated in the implementation process of the SEVESO III Directive into national legislation. He conducts inspections in Seveso establishments. He has authored numerous analyses and lectures on the subjects of process safety and risk assessment. He is also a manager in a scientific research project entitled "Software for risk assessment in industrial establishments generating hazards beyond their area".

ML. KPT. GRZEGORZ SOBIESZEK, M.ENG. - completed the Fire Service College of the State Fire Service in Częstochowa. He graduated in Chemistry from the Faculty of Advanced Technologies and Chemistry of the Military University of Technology in Warsaw. He obtained his MSc degree at the Fire Safety Engineering Faculty of the Main School of Fire Service. He completed postgraduate studies for firefighters aspiring for officer positions involving the management of rescue operations at the Main School of Fire Service. Since 2013 he has been in active service at the Inspection and Evaluation Department of the Mazovian Headquarters of the State Fire Service in Warsaw. He is currently employed as a specialist. 